This is an author produced version of a paper published in Dalton Transactions: an international journal of inorganic chemistry. This paper has been peer-reviewed and is proof-corrected, but does not include the journal pagination.

Citation for the published paper:

Eklund, L. \& Persson, I. (2014) Structure and hydrogen bonding of the hydrated selenite and selenate ions in aqueous solution. Dalton Transactions: an international journal of inorganic chemistry. Volume: 43 Number: 17, pp 6315-6321.

http://dx.doi.org/10.1039/c3dt53468e.

Access to the published version may require journal subscription. Published with permission from: Royal Society of Chemistry.

Epsilon Open Archive http://epsilon.slu.se 


\title{
Structure and hydrogen bonding of the hydrated selenite and selenate ions in aqueous solution
}

\author{
Lars Eklund and Ingmar Persson*
}

Department of Chemistry and Biotechnolgy, Swedish University of Agricultural Sciences, P.O.Box 7015, SE-750 07 Uppsala, Sweden.

\section{Graphical Entry}

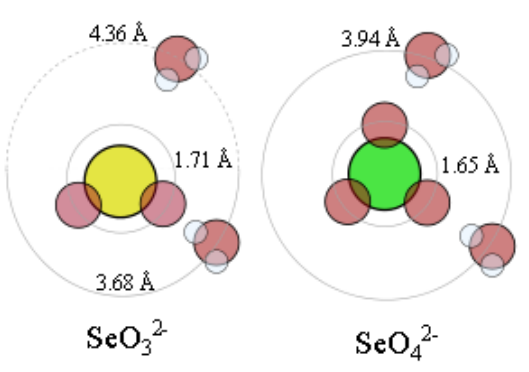

\section{Textual abstract}

The selenite ion has an asymmetric hydration sphere with loosely electrostatically bound water molecules outside the free electron pair. 


\begin{abstract}
Structure and hydrogen bonding of the hydrated selenite, $\mathrm{SeO}_{3}{ }^{2-}$, and selenate, $\mathrm{SeO}_{4}{ }^{2-}$, ions have been studied in aqueous solution by large angle X-ray scattering (LAXS), EXAFS and double difference infrared (DDIR) spectroscopy. The mean Se-O bond distances are 1.709(2) and 1.657(2) A, respectively, as determined by LAXS, and 1.701(3) and 1.643(3) ̊ by EXAFS. These bond distances are slightly longer than the mean distances found in the solid state, 1.691 and $1.634 \AA$, respectively. The structures of $\mathrm{HSeO}_{3}{ }^{-}, \mathrm{H}_{2} \mathrm{SeO}_{3}$ and $\mathrm{HSeO}_{4}{ }^{-}$in aqueous solution have been determined by EXAFS giving the same Se-O bond distances as for the selenite and selenate ions, respectively. The mean $\mathrm{Se}^{\cdots} \mathrm{O}_{\mathrm{w}}$ distance to the water molecules hydrogen binding to selenite oxygens is 3.87(2) $\AA$, and it is 4.36(8) $\AA$ to those clustered outside the lone electronpair. The selenate ion has a symmetric hydration shell with only one $\mathrm{Se}^{\cdots} \mathrm{O}_{\mathrm{w}}$ distance, 3.94(2) $\AA$. The mean Se-O $\cdots \mathrm{O}_{\mathrm{w}}$ angle in the hydrated selenite ion is $114.5^{\circ}$, and the large temperature factor of the $\mathrm{Se}^{\cdots} \mathrm{O}_{\mathrm{w}}$ distance strongly indicate equilibrium between two and three water molecules hydrogen bound to the selenite oxygens. The mean Se-O $\cdots \mathrm{O}_{\mathrm{w}}$ angle in the hydrated selenate ion is $120^{\circ}$ which strongly indicate that two water molecules hydrogen bind to the selenate oxygens. The DDIR spectra show peaks for affected water bound to the selenite and selenate ions at $2491 \pm 2$ and $2480 \pm 39 \mathrm{~cm}^{-1}$, respectively, compared to $2509 \mathrm{~cm}^{-1}$ in pure water. This shows that the selenite and selenite ions shall be regarded as weak structure makers.
\end{abstract}




\section{Introduction}

The selenium oxo acids and their salts have many similarities with the corresponding sulfur oxo acids, including similar physico-chemical parameters as e.g. the acid dissociations constants; $\mathrm{H}_{2} \mathrm{SeO}_{4}: \mathrm{p} K_{\mathrm{a} 2}=1.70 ; \mathrm{H}_{2} \mathrm{SO}_{4}: \mathrm{p} K_{\mathrm{a} 2}=1.99 ; \mathrm{H}_{2} \mathrm{SeO}_{3}, \mathrm{p} K_{\mathrm{a} 1}=2.62, \mathrm{p} K_{\mathrm{a} 2}=8.32, \mathrm{H}_{2} \mathrm{SO}_{3} ; \mathrm{p} K_{\mathrm{a} 1}=1.85$, $\mathrm{p} K_{\mathrm{a} 2}=7.20 .{ }^{1}$ The structure and hydrogen bonding of the hydrated sulfite and sulfate ions have previously been studied in aqueous solution using large angle X-ray scattering (LAXS) and double difference infrared spectroscopy as well as simulations on QMCF MD level. ${ }^{2-4}$ Three water molecules are hydrogen bound to each oxygen atom for both ions. Furthermore, some water molecules are clustered outside the lone electron-pair of the sulfite ion at a reasonably welldefined distance. ${ }^{4}$ In studies of other oxoanions it has been shown that the number of hydrogen bound water molecules seems to decrease when the central atom belong to the third and fourth series. The arsenate ions, independent of degree of protonation, and arsenous and telluric acid all bind approximately two water molecules to each oxygen. ${ }^{5}$ The sulfate and sulfite ions are both weak structure makers, thus the hydrogen bond between the sulfate/sulfite oxygens and the hydrating water molecules is slightly shorter and stronger than between water molecules in the aqueous bulk. ${ }^{2-4}$

It is of fundamental interest to compare the hydration of the selenite and sulfite ions as they have asymmetric hydration shells due to the presence of a free electron pair in the fourth tetrahedron vortex. Previously reported simulations of the water exchange dynamics of the hydrated sulfate and sulfite ions in aqueous solution showed significantly different mechanisms. ${ }^{4}$ The hydrogen bound water molecules on the sulfate oxygen exchange directly with a bulk water. On the other hand, the asymmetrically hydrated sulfite ion exchanges almost all water molecules in close vicinity of the free electron pair with a transport path from the sulfite oxygens to this region. ${ }^{4}$ The aim of this study is to determine the structures and the hydrogen bond strength of the hydrated oxo selenium ions in aqueous solution, and to make comparisons with other hydrated oxo anions in aqueous solution. Normalized Se K edge XANES spectra are reported to show whether it is possible to use them for analytical purposes as they are for the corresponding $\mathrm{S}$ kedge XANES spectra. ${ }^{6}$ An overview of the structures of the $\mathrm{H}_{2} \mathrm{SeO}_{3}-\mathrm{HSeO}_{3}{ }^{-}-\mathrm{SeO}_{3}{ }^{2-}$ and $\mathrm{H}_{2} \mathrm{SeO}_{4}-\mathrm{HSeO}_{4}{ }^{-}-\mathrm{SeO}_{4}{ }^{2-}$ systems will be presented and compared to the results obtained for other oxo anions. 


\section{Experimental}

Chemicals. Sodium selenite, $\mathrm{Na}_{2} \mathrm{SeO}_{3}$ (analytical grade, Fluka), selenous acid, $\mathrm{H}_{2} \mathrm{SeO}_{3}$ (Fluka, $<99 \%$ ), sodium selenate, $\mathrm{Na}_{2} \mathrm{SeO}_{4}$, sodium selenate decahydrate, $\mathrm{Na}_{2} \mathrm{SeO}_{4} \cdot 10 \mathrm{H}_{2} \mathrm{O}$ (both analytical grade, Fluka), hydrochloric acid (extrapure, Merck) and heavy water, $\mathrm{D}_{2} \mathrm{O},(99.96$ atom $\% \mathrm{D}$, Aldrich) were used without further purification.

Solutions. The aqueous solutions for the LAXS and EXAFS experiments were prepared by dissolving weighed amounts of selenous acid, sodium selenite, sodium selenate decahydrate and/or hydrochloric acid in Milli Q filtered water. One drop of $1.0 \mathrm{~mol} \cdot \mathrm{dm}^{-3}$ sodium hydroxide was added to the sodium selenite and selenate solutions to increase the $\mathrm{pH}$ values to 12.0. The composition of the studied solutions is given in Table S1. For the IR measurements matched concentration series in both pure water and $4 \% \mathrm{w} / \mathrm{w} \mathrm{D}_{2} \mathrm{O} / \mathrm{H}_{2} \mathrm{O}$ were prepared for sodium selenate and selenite.

LAXS. The scattering of MoK $\alpha$ X-ray radiation, $\lambda=0.7107 \AA$, from the free surface of the aqueous sodium selenite and selenate solutions were measured in a large angle $\Theta-\Theta$ goinometer described elsewhere. ${ }^{7}$ The solution was contained in a teflon cup filled until a positive meniscus was observed generating a flat surface in the irradiated region. The container was placed inside an air-tight radiation shield with beryllium windows. The scattered radiation was monchromatised using a $\mathrm{LiF}$ (200) single crystal focusing monochromator. The scattering was determined at 446 angles in the angle range of $0.5<\Theta<65^{\circ}$, where the scattering angle is $2 \Theta$. At each angle 100,000 X-ray quanta where accumulated, and the entire angle range was scanned twice corresponding to a statistical error of about $0.3 \%$. The divergence of the $\mathrm{x}$-rays was defined through combination of divergence-collecting-focal slits of $1 / 4^{\circ}-1 / 2{ }^{\circ}-0.2 \mathrm{~mm}$ and $1^{\circ}-2^{\circ}$ $0.2 \mathrm{~mm}$. Three different $\Theta$-regions were scanned to get a suitable counting rate and change in angle, with overlapping regions to enable scaling of the data. The data collection and treatment is described in detail elsewhere. ${ }^{7}$ All data treatment was carried out using the KURVLR program, ${ }^{8}$ and the structural parameters in the theoretical model where refined by minimizing $U=$ $w(s) \sum s^{2}\left[i_{\text {exp }}(s)-i_{\text {calc }}(s)\right]^{2}$ using the STEPLR program. ${ }^{9,10}$ The experimental data was normalized to a stoichiometric unit containing one selenium atom, using the scattering factors $f$ for neutral

atoms, including corrections for anomalous dispersion, $\Delta f^{\prime}$ and $\Delta f^{\prime \prime},{ }^{11}$ Compton scattering ${ }^{12,13}$ and multiple scattering events. 
$\boldsymbol{X A F S}$. K-edge X-ray absorption spectra of the aqueous solutions of selenous acid, sodium hydrogenselenite, selenite, hydrogenselenate and selenate, as listed in Table 1, were collected at the wiggler beam-line I811 at the MAX-lab synchrotron light facility at Lund University, Sweden. The facility operated at $1.5 \mathrm{GeV}$ and a maximum current of $250 \mathrm{~mA}$. A double crystal $\mathrm{Si}(111)$ monochromator was used. The second monochromator crystal was detuned to $60 \%$ of maximum intensity at the end of the scans to minimize higher harmonics. The solutions were contained in cells made of a $1.5 \mathrm{~mm}$ Teflon spacer and $6 \mu \mathrm{m}$ polypropylene film hold together with titanium frames, and the solids, diluted and carefully ground with boron nitride, were contained in $1.0 \mathrm{~mm}$ aluminum frames covered with X-ray transparent tape. The experiments were performed simultaneously in transmission and fluorescence mode at the Se K edge using gas filled ion chambers and a PIPS (Passivated Implanted Planar Silicon) detector. ${ }^{14}$ Data treatment was performed with the computer program package EXAFSPAK. ${ }^{15}$ Ab initio calculated phase and amplitude parameters, used by the EXAFSPAK program, were computed by the FEFF7 program. ${ }^{16}$ The K edge Se XANES spectra were normalized to the absorption of one at $12775 \mathrm{eV}$ for a comparison of the edge features and white line intensity maxima.

Double difference infrared spectroscopy (DDIR). The IR measurements were performed in a continuous series on a Perklin-Elmer Spectrum 100 FT-IR Spectrometer with matched concentrations of the two solutions in a temperature controlled liquid cell using $3 \mathrm{~mm} \mathrm{CaF}_{2}$ windows (PIKE Technologies), the cell was thermostated to $25.0 \pm 0.5{ }^{\circ} \mathrm{C}$. ${ }^{17}$ Each spectrum is an average of 256 scans with $4 \mathrm{~cm}^{-1}$ resolution in the range $4000-900 \mathrm{~cm}^{-1}$. The path length was $0.035280 \mathrm{~mm}$ as determined through interference. ${ }^{17}$ By measuring the same concentration of salt in both pure water and water containing $8 \% \mathrm{HDO}$, and then subtracting the spectrum of pure water one gets an infrared spectrum of the HDO molecules different from those in the aqueous bulk. By taking the derivative of these spectra $\sigma \epsilon / \sigma \mathrm{m}$ where $\epsilon$ denotes the spectrum and $\mathrm{m}$ the molality of the solution then subtracting $\left(1 / \mathrm{N}^{*} \mathrm{M}\right)^{*} \sigma \epsilon / \sigma \mathrm{m}$ from the spectrum of pure water, where $N$ is the affected number of water and $\mathrm{M}$ is the mean molar mass in $\mathrm{kg} / \mathrm{mol}$ of water and partially heavy water, as described by Kristiansson et al. and Gampe et al.; ${ }^{18-20}$ the affected water peaks ascribed to water molecules bound to cations or anions are obtained through PCA. All calculations of the spectra were carried out using GRAMS AI version 8.0 (Thermo-Fisher Scientific) and RAZOR tools (Spectrum Square Associates), and two Array the Basic program YANUZ.AB was used to calculate the derivatives of the spectra. ${ }^{21}$ 
Crystal structure database search. Reported crystal structures containing individual units of $\mathrm{SeO}_{3}{ }^{2-}, \mathrm{HSeO}_{3}{ }^{-} \mathrm{H}_{2} \mathrm{SeO}_{3}, \mathrm{SeO}_{4}{ }^{2-}, \mathrm{HSeO}_{4}{ }^{-}$and $\mathrm{H}_{2} \mathrm{SeO}_{4}$ were collected from the Cambridge Structural Database and the Inorganic Crystal Structure Database. ${ }^{22,23}$ In order for the different structures to be potentially representative for comparison with hydrated species in aqueous solution, only those in which selenite or selenate oxygen atoms binding to neutral species or univalent ligand atoms were considered. Compounds in which $\mathrm{Ag}^{+}$or $\mathrm{Tl}^{+}$bind directly to the selenite or selenate oxygen atoms have not been included, as the soft character of these metal ions may alter the electron distribution in the entire anion and thereby their structure.

\section{Results and Discussion}

Large angle $X$-ray scattering

The RDF of the aqueous solution of sodium selenite shows three peaks refined to 1.709(4), 2.873(8) and 3.87(4) $\AA$, which correspond to the Se-O bond distance in the hydrated selenite ion, the $\mathrm{O}_{\mathrm{w}} \cdots \mathrm{O}_{\mathrm{w}}$ and $\mathrm{O} \cdots \mathrm{O}_{\mathrm{w}}$ distances, and $\mathrm{Se} \cdots \mathrm{O}_{\mathrm{w}}$ distances between the selenium atom and the hydrating water molecules, respectively, Figure 1. The latter peak is unusually broad including an additional $\mathrm{Se} \cdots \mathrm{O}$ distance at 4.36(8) $\AA$ assigned to the mean distance to the water molecules clustered outside the lone electron pair on selenium, as also found for the hydrated sulfite ion. ${ }^{4}$ The mean $\mathrm{O}_{\mathrm{w}} \cdots \mathrm{O}_{\mathrm{w}}$ distances in the aqueous bulk and between selenite oxygens and hydrating water molecules is slightly shorter, $2.873(4) \AA$, than normally observed in an aqueous bulk with solutes, $2.89 \AA$. The observed mean $\mathrm{O} \cdots \mathrm{O}$ distance indicate that the $\mathrm{O} \cdots \mathrm{O}_{\mathrm{w}}$ distance is in the range 2.83-2.86 $\AA$, showing that the selenite ion is a structure maker but as such slightly weaker than the selenate ion which is in agreement with the DDIR measurements, see below. Assuming an $\mathrm{O} \cdots \mathrm{O}_{\mathrm{w}}$ distance of $2.85 \AA$, the $\angle \mathrm{Se}-\mathrm{O}-\mathrm{O}_{\mathrm{w}}$ angle becomes $114^{\circ}$, thus between the expected values of 109.47 and 120.0 for tetrahedral and trigonal configuration around the selenite oxygens. Furthermore, the temperature coefficient is very large, twice the value observed for the selenate ion, Table 2, which shows an unusually broad distance distribution. It seems therefore likely that there is an equilibrium between two and three water molecules hydrogen binding to the selenite oxygens. The Na-O bond distances in the hydrated sodium ion is observed as a weak shoulder at 2.42(4) $\AA$, which is in agreement with previous studies. ${ }^{24}$

The experimental radial distribution function (RDF) of the aqueous solution of sodium 
selenate shows three peaks refined to 1.657(4), 2.861(8) and 3.94(4) A. These correspond to the Se-O bond distance in the hydrated selenate ion, the $\mathrm{O}_{\mathrm{w}} \cdots \mathrm{O}_{\mathrm{w}}$ distances in the aqueous bulk and $\mathrm{O} \cdots \mathrm{O}_{\mathrm{w}}$ distances between selenate oxygens and hydrating water molecules, and $\mathrm{Se}^{\cdots} \mathrm{O}_{\mathrm{w}}$ distances between selenium atom the hydrating water molecules, respectively, Figure 2. The mean Na-O bond distance in the hydrated sodium ion is observed as a weak shoulder at 2.43(4) $\AA$. The observed Se-O bond distance in aqueous solution is slightly longer, $0.023 \AA$ longer than the mean Se-O bond distance in solid selenate salts, Table S2. This is within the expected range as the hydration through the hydrogen bonding electrostatically interacts with the selenate oxygens. The increase in the Se-O bond length is of the same order as previously observed for the sulfate, sulfite, arsenate, arsenite and perchlorate ions. ${ }^{2,4,5,25}$ The $\mathrm{O}_{\mathrm{w}} \cdots \mathrm{O}_{\mathrm{w}}$ distances in the aqueous bulk and between selenate oxygens and hydrating water molecules are not possible to separate, and a mean $\mathrm{O} \cdots \mathrm{O}$ distance of $2.861(8) \AA$ was obtained. This mean $\mathrm{O}_{\mathrm{w}} \cdots \mathrm{O}_{\mathrm{w}}$ distance is slightly shorter than normally observed for the $\mathrm{O}_{\mathrm{w}} \cdots \mathrm{O}_{\mathrm{w}}$ distance in aqueous bulk, $2.89 \AA$. This strongly indicates that the $\mathrm{O} \cdots \mathrm{O}_{\mathrm{w}}$ distance is in the range $2.81-2.85 \AA$, showing that the selenate ion is a structure maker as also shown by DDIR measurements. The distance between the central Se atom and the oxygens of the hydrating water molecules, $\mathrm{Se} \cdots \mathrm{O}_{\mathrm{w}}, 3.94 \AA$, gives a $\angle \mathrm{Se}-\mathrm{O}-\mathrm{O}_{\mathrm{w}}$ angle of $120^{\circ}$ assuming a mean $\mathrm{O} \cdots \mathrm{O}_{\mathrm{w}}$ distance of $2.83 \AA$. As the water molecules hydrating the selenate oxygens are electrostatically bound the observed angle of $120^{\circ}$ strongly indicates that on average two water molecules are hydrogen bound to the selenate oxygens. This is in contradiction to the sulfate, sulfite and perchlorate ions where three water molecules are hydrogen bound to each oxygen, but in agreement with heavier oxo anions as arsenate and arsenite and the neutral telluric acid. ${ }^{5}$ The difference function in Figures 1 and 2 has almost identical shape strongly indicating that the structure of the aqueous bulk not included in the models applied is the same in both samples studied.

\section{EXAFS}

The EXAFS spectra of the hydrogenselenate and selenate ions in aqueous solution and the solids sodium selenate and sodium selenate decahydrate display almost identical EXAFS spectra, Figure 3. Refinement of the structure parameters shows that the $\mathrm{Se}-\mathrm{O}$ bond distances in the selenate and hydrogenselenate ions in aqueous solution are 1.643 and $1.642 \AA$, respectively, Table 3. The Debye-Waller coefficient is slightly larger for the hydrogenselenate ion than for the selenate ion, 0.0027 and $0.0020 \AA$, respectively. This is expected as the bond distance 
distribution is larger due to that the $\mathrm{Se}-\mathrm{O}$ bond distance on the protonated oxygen in the hydrogenselenate ion is on average $0.090 \AA$ longer than to the non-protonated ones, 1.705 and $1.615 \AA$, in reported solid state structures, see Table S2. However, the mean Se-O bond distance in the selenate and hydrogenselenate ions are indistinguishable from each other, 1.634 and 1.638 $\AA$, respectively, see detailed discussion below.

The selenite system show the same structural behavior as the selenate one with very similar mean Se-O bond distances in selenous acid, and the hydrogenselenate and selenite ions, 1.714(3), 1.704(3) and $1.701 \AA$, respectively, Table 4. Furthermore, the Debye-Waller coefficient is larger for the hydrogenselenate ion and selenous acid than for the selenite ion, Table 4. In the reported selenite structures in the solid state the mean Se-O bond distance is $1.700,1.698$ and $1.691 \AA$ for $\mathrm{H}_{2} \mathrm{SeO}_{3}, \mathrm{HSeO}_{3}{ }^{-}$and $\mathrm{SeO}_{3}{ }^{2-}$, respectively, and with mean difference between protonated and nonprotonated oxygens of 0.118 and $0.105 \AA$ for $\mathrm{H}_{2} \mathrm{SeO}_{3}$ and $\mathrm{HSeO}_{3}{ }^{-}$, respectively, Table $\mathrm{S} 2$. The Se-O bond distances in the hydrated selenite and selenate species in aqueous solution is slightly longer than the anhydrous solids due to the hydration effects.

\section{Summary of structure determination in aqueous solution}

LAXS and EXAFS are complementary methods as described in more detail elsewhere. ${ }^{26}$ Bond distances are more accurately determined by EXAFS, while long distances with large distance distribution can only be determined by LAXS. ${ }^{26}$ The Se-O bond distances for the selenite and selenate ions are slightly longer as determined by LAXS than by EXAFS, and they are more accurately determined by EXAFS, Tables 1-3. On the other hand, the long distances giving information about distances to hydrating water molecules observed by LAXS are not seen by EXAFS. Thus, it is the combination of the two methods which give the unique information about the hydrated selenite and selenate ions reported here.

\section{XANES spectra of selenite and selenate ions}

The white line maximum of the selenite and selenate ions are at 12664.65 and $12667.75 \mathrm{eV}$, respectively, independent of degree of protonation, Figure 5. There is only a minor difference in white-line intensity between the hydrogenselenate and selenate ions otherwise the XANES spectra are identical. On the other hand, the XANES spectra of the selenite and hydrogen selenite ions and selenous acid have very different features even though the white-line maxima are the same, Figure 5, which may be used to distinguish the different protonated forms of selenite, while 
this seems not to the case for the selenate species.

\section{Fourier transform infrared spectroscopy}

Analysis of the affected spectra of the hydrated selenite ion, Figure 6, through spectral decomposition generates number of affected waters of $N=15.7$. The sodium peak at $2534 \pm 9 \mathrm{~cm}^{-1}$ is in good agreement with earlier work. ${ }^{20}$ The main anionic peak of the hydrated selenite ion $\left(\left[\mathrm{SeO}_{3}\left(\mathrm{H}_{2} \mathrm{O}\right)_{7.5}\left(\mathrm{H}_{2} \mathrm{O}\right)_{\sim 3}\right]^{2-}\right)$ is at $2491 \pm 2 \mathrm{~cm}^{-1}$. The position of the anionic peak indicates that selenite ion is a weak structure maker with molecular interaction energy of water $\Delta U_{\mathrm{w}}=-45.2 \mathrm{~kJ}$ $\mathrm{mol}^{-1}$ derived from $v_{\mathrm{OD}}$ using the Badger-Bauer rule ${ }^{27}$ using calculation procedure described in detail in earlier studies. ${ }^{18,19}$

It was possible to separate the contributions from the sodium and selenate ions in the affected DDFTIR spectra, Figure 7. The peak ascribed to the selenate ion $\left(\left[\mathrm{SeO}_{4}\left(\mathrm{H}_{2} \mathrm{O}\right)_{8}\right]^{2-}\right)$ has a maximum at $2480 \pm 39 \mathrm{~cm}^{-1}$; the corresponding frequency for sulfate $\left(\left[\mathrm{SO}_{4}\left(\mathrm{H}_{2} \mathrm{O}\right)_{12}\right]^{2-}\right)^{-}$is $2477 \pm 8$ $\mathrm{cm}^{-1}{ }^{3}$ Transforming the $v_{\mathrm{OD}}$ for the affected water peak of the selenate ion to molecular interaction energy of water it becomes $\Delta U_{\mathrm{w}}=-47.4 \mathrm{~kJ} \cdot \mathrm{mol}^{-1}$. In the hydrated sodium selenate the peak ascribed to the sodium ion was observed at $2539 \pm 18 \mathrm{~cm}^{-1}$. The peak was a slightly wider peak than in earlier work, but the peak position is within expected range.

\section{Structure of selenate and selenite ions in solid state and aqueous solution}

The Se-O bond distances in available data bases for the $\mathrm{SeO}_{3}{ }^{2-}, \mathrm{HSeO}_{3}{ }^{-} \mathrm{H}_{2} \mathrm{SeO}_{3}, \mathrm{SeO}_{4}{ }^{2-}, \mathrm{HSeO}_{4}{ }^{-}$ and $\mathrm{H}_{2} \mathrm{SeO}_{4}$ systems are summarized in Table $\mathrm{S} 2$. The selenite and selenate ions have truncated tetrahedral and regular tetrahedral structure, respectively, with all Se-O bond distances the same or almost the same, mean 1.634 and $1.691 \AA$, Table S2. As shown above, the Se-O bond distances increase by 0.01-0.02 $\AA$ at hydration in aqueous solution. The structures of $\mathrm{HSeO}_{3}{ }^{-}$ $\mathrm{H}_{2} \mathrm{SeO}_{3}, \mathrm{HSeO}_{4}{ }^{-}$and $\mathrm{H}_{2} \mathrm{SeO}_{4}$ display a different pattern with the $\mathrm{Se}-\mathrm{O}$ bonds with a protonated oxygen significantly longer than non-protonated oxygens. The difference in mean Se-O bond distance in these two kinds of oxygens in the $\mathrm{HSeO}_{3}{ }^{-}$and $\mathrm{HSeO}_{4}{ }^{-}$ions is 0.107 and $0.090 \AA$, respectively, and about the same differences are found for $\mathrm{H}_{2} \mathrm{SeO}_{3}$ and $\mathrm{H}_{2} \mathrm{SeO}_{4}, 0.118$ and 0.089 $\AA$, respectively, Table $\mathrm{S} 2$. This difference is expected to be maintained also in aqueous solution as the difference in hydrogen bond strength when the selenite/selenate oxygen is a hydrogen bond acceptor or the $\mathrm{OH}$ group a hydrogen bond donor is expected to be small. It is not possible to distinguish such small differences with the structural methods applicable on solutions available 
today. However, the mean Se-O bond distance for the protonated forms of selenite and selenate is very close to the mean Se-O bond distance in the selenate and selenite ions with 1.691, 1.699 and $1.700 \AA$ for $\mathrm{SeO}_{3}{ }^{2-}, \mathrm{HSeO}_{3}{ }^{-}$and $\mathrm{H}_{2} \mathrm{SeO}_{3}$, respectively, and $1.634,1.638$ and $1.642 \AA$ for $\mathrm{SeO}_{4}{ }^{2-}$, $\mathrm{HSeO}_{4}{ }^{-}$and $\mathrm{H}_{2} \mathrm{SeO}_{4}$, respectively, Table $\mathrm{S} 2$. The very same structural behavior has been observed in the arsenic and arsenous acid systems as described in detail elsewhere. ${ }^{5}$

\section{Conclusions}

The structures of the hydrated selenite and selenate ions in aqueous solution show a single shell of water molecules hydrogen bound to the oxygen atoms. On average two water molecules hydrogen bind to each selenate oxygen, while an equilibrium between two and three water molecules hydrogen bind to each selenite oxygen. These numbers are lower than for the corresponding sulfuroxo anions where three water molecules are hydrogen bound to each of the

oxygen. ${ }^{2,4}$ Additionally, outside the lone electron-pair on the selenite ion ca. three water molecules are clustered at long distance, as also found for the sulfite ion. ${ }^{4}$ Selenite and selenate ions are both weak structure makers as shown by the O-D stretching frequencies of the hydrating water molecules in comparison with pure water. The symmetric and more oxidized selenate ion is a slightly stronger structure maker than the selenite ion but slightly weaker than the sulfate and fluoride ions. ${ }^{20}$ The Se K edge XANES spectra of the selenite and selenate species have whiteline maxima at 12664.65 and $12667.75 \mathrm{eV}$, respectively. The white-line features are significantly different for the selenite species, while they are almost identical for the selenate ones, Figure 5.

\section{Acknowledgment}

The financial support from the Swedish Research Council is gratefully acknowledged. Portions of this research were carried out at beam-line I811, MAX-lab synchrotron radiation source, Lund University, Sweden. Funding for the beam-line I811 project was kindly provided by “The Swedish Research Council and The Knut och Alice Wallenbergs Stiftelse." 


\section{References}

1. CRC Handbook of Chemistry and Physics, $93^{\text {rd }}$ Ed., W. M. Haynes, Ed., p. 5-93,

2. V. Vchirawongkwin, B. M. Rode and I. Persson, J. Phys. Chem. B, 2007, 111, 4150-4155.

3. P.-Å. Bergström, J. Lindgren, O. Kristiansson, J. Phys. Chem., 1991, 95, 8575-8580.

4. L. Eklund, T. S. Hofer, A. Pribil, B. M. Rode an I. Persson, Dalton Trans., 2012, 41, 52095216.

5. J. Mähler and I. Persson, Dalton Trans., 2013, 42, 1364-1377.

6. G. Almkvist, K. Boye and I. Persson, J. Synchrotron Rad., 2010, 17, 683-688.

7. C. M. V. Stålhandske, I. Persson, M. Sandström and E. Kamienska-Piotrowicz, Inorg. Chem., 1997, 36, 3174-3182.

8. G. Johansson and M. Sandström, Chem. Scr., 1973, 4, 195-198.

9. M. Molund and I. Persson, Chem. Scr., 1985, 25, 197-197.

10. J. P. Chandler, Behav. Sci. 1969, 14, 81-82.

11. A. J. C. Wilson, Ed. International Tables for Crystallography; Kluwer Academic Publishers: Dordrecht, The Netherlands, 1995; Vol. C.

12. D. T. Cromer, J. Chem. Phys., 1967, 47, 1892-1894.

13. D. T. Cromer, J. Chem. Phys., 1969, 50, 4857-4859.

14. http://www.canberra.com/products/detectors/pips-detectors.asp

15. G. N. George and I. J. Pickering, EXAFSPAK - A suite of Computer Programs for Analysis of $X$-ray absorption spectra; SSRL: Stanford, CA.

16. S. I. Zabinsky, J. J. Rehr, A. Ankudinov, R. C. Albers and M. J. Eller, Phys. Rev. B, 1995, 52, 2995-3009.

17. http://www.piketech.com/skin/fashion_mosaic_blue/application-pdfs/CalculatingPathlengthLiquidCells.pdf (downloaded January 9, 2014)

18. O. Kristiansson, J. Lindgren and J. De Villepin, J. Phys. Chem., 1988, 92, 2680-2685.

19. J. Stangret and T. Gampe, J. Phys. Chem., 1999, 103, 3778-3783.

20. J. Stangret and T. Gampe, J. Phys. Chem. A, 2002, 106, 5393-5402, and references therein. 
21. Array Basic programs YANUZ.AB provided by M. Smiechowski, Technical University of Gdansk, Gdansk, Poland.

22. F. H.Allen, Acta Crystallogr. Sect. B, 2002, 58, 380-388.

23. Inorganic Crystal Structure Database; FIZ: Karlsruhe, 2013.

24. J. Mähler and I. Persson, Inorg. Chem., 2012, 51, 425-438.

25. I. Persson, K. Lyczko, D. Lundberg, L. Eriksson and A. Placzek, Inorg. Chem., 2011, 50, 1058-1072.

26. I. Persson, M. Sandström, H. Yokoyama and M. Chaudhry, Z. Naturforsch., Sect. A. 1995, 50, 21-37.

27. R. M. Badger and S. H. Bauer, J. Chem. Phys., 1937, 5, 839-851. 
Table 1. Mean bond distances, $d / \AA$, number of distances, $N$, and temperature coefficients, $b / \AA^{2}$, the half-height full width, $l / \AA$, in the LAXS study of aqueous sodium selenite and selenate solutions at room temperature.

\begin{tabular}{|c|c|c|c|c|c|}
\hline Species & action & $N$ & $d$ & $b$ & $l$ \\
\hline \multicolumn{6}{|c|}{$1.5006 \mathrm{~mol} \cdot \mathrm{dm}^{-3} \mathrm{Na}_{2} \mathrm{SeO}_{3}$ in water } \\
\hline \multirow[t]{3}{*}[\mathrm{SeO}_{3}(\mathrm{H}_{2}\mathrm{O})_{7.5}(\mathrm{H}_{2}\mathrm{O})_{\sim3}]{$^{2-}$} & $\mathrm{Se}-\mathrm{O}$ & 3 & $1.709(2)$ & $0.0031(3)$ & 0.079 \\
\hline & $\mathrm{Se} \cdots \mathrm{O}_{\mathrm{II}}$ & 7.5 & $3.87(2)$ & $0.048(2)$ & 0.33 \\
\hline & $\mathrm{Se} \cdots \mathrm{O}_{\mathrm{II}}$ & $\sim 3$ & $4.36(4)$ & $0.027(2)$ & 0.23 \\
\hline $\mathrm{Na}\left(\mathrm{H}_{2} \mathrm{O}\right)_{6}^{+}$ & $\mathrm{Na}-\mathrm{O}_{\mathrm{w}}$ & 6 & $2.42(2)$ & $0.023(2)$ & 0.21 \\
\hline Aqueous bulk & $\mathrm{O}_{\mathrm{w}} \cdots \mathrm{O}_{\mathrm{w}}$ & 2 & $2.874(4)$ & $0.025(4)$ & 0.22 \\
\hline \multicolumn{6}{|c|}{$1.5066 \mathrm{~mol} \cdot \mathrm{dm}^{-3} \mathrm{Na}_{2} \mathrm{SeO}_{4}$ in water } \\
\hline \multirow[t]{2}{*}[\mathrm{SeO}_{4}(\mathrm{H}_{2}\mathrm{O})_{8}]{$^{2-}$} & $\mathrm{Se}-\mathrm{O}$ & 4 & $1.657(2)$ & $0.0022(3)$ & 0.066 \\
\hline & $\mathrm{Se} \cdots \mathrm{O}_{\mathrm{II}}$ & 8 & $3.94(2)$ & $0.028(2)$ & 0.24 \\
\hline $\mathrm{Na}\left(\mathrm{H}_{2} \mathrm{O}\right)_{6}^{+}$ & $\mathrm{Na}-\mathrm{O}_{\mathrm{w}}$ & 6 & $2.43(2)$ & $0.022(2)$ & 0.21 \\
\hline Aqueous bulk & $\mathrm{O}_{\mathrm{w}} \cdots \mathrm{O}_{\mathrm{w}}$ & 2 & $2.861(4)$ & $0.018(4)$ & 0.19 \\
\hline
\end{tabular}


Table 2. Mean bond distances, $d / \AA$, number of distances, $N$, and Debye-Waller coefficients, $\sigma^{2} / \AA^{2}$, in the EXAFS study of aqueous sodium selenite solutions and of solid sodium selenite salts at room temperature. The refinements were performed in the $k$ range $2-13 \AA^{-1}$. $F / \%$ is the goodness of fit as defined in the EXAFSPAK program.

\begin{tabular}{llllll}
\hline Species & Interaction & $N$ & $d$ & $\sigma^{2}$ & $F$
\end{tabular}

$0.50 \mathrm{~mol} \cdot \mathrm{dm}^{-3} \mathrm{NaHSeO}_{3}$ in water

$\begin{array}{llllll}\mathrm{H}_{2} \mathrm{SeO}_{3} & \mathrm{Se}-\mathrm{O} & 3 & 1.714(1) & 0.0044(1) & 14.2 \\ & \mathrm{MS} 1 & 9 & 3.09(1) & 0.008(2) \\ & \mathrm{MS}\left(\mathrm{SeO}_{3}\right)^{\text {a }} & 3+9 & 3.41(3) & 0.011(4)\end{array}$

$0.50 \mathrm{~mol} \cdot \mathrm{dm}^{-3} \mathrm{NaHSeO}_{3}$ in water

$\begin{array}{llllll}\mathrm{HSeO}_{3}{ }^{-} & \mathrm{Se}-\mathrm{O} & 3 & 1.704(1) & 0.0043(1) & 9.4 \\ \mathrm{MS} 1 & 9 & 3.030(5) & 0.0054(5) \\ & \mathrm{MS}\left(\mathrm{SeO}_{3}\right)^{\mathrm{a}} & 3+9 & 3.395(4) & 0.0064(4)\end{array}$

$0.50 \mathrm{~mol} \cdot \mathrm{dm}^{-3} \mathrm{Na}_{2} \mathrm{SeO}_{3}$ in water

$\begin{array}{llllll}\mathrm{SeO}_{3}{ }^{2-} & \mathrm{Se}-\mathrm{O} & 3 & 1.701(1) & 0.0022(1) & 13.3 \\ & \mathrm{MS} 1 & 9 & 3.08(2) & 0.004(2) \\ & \mathrm{MS}\left(\mathrm{SeO}_{3}\right)^{\mathrm{a}} & 3+9 & 3.44(2) & 0.007(3)\end{array}$

Solid $\mathrm{Na}_{2} \mathrm{SeO}_{3}$

$\begin{array}{llllll}\mathrm{SeO}_{3}{ }^{2-} & \mathrm{Se}-\mathrm{O} & 3 & 1.700(1) & 0.0011(1) & 14.3 \\ & \mathrm{MS} 1 & 9 & 3.061(6) & 0.0046(6) \\ & \mathrm{MS}\left(\mathrm{SeO}_{3}\right)^{\mathrm{a}} & 3+9 & 3.388(8) & 0.0052(8)\end{array}$

${ }^{a}$ The multiple scattering of the selenite ion with cut-off tetrahedral geometry have two separate paths with double Se-O bond distance with the frequencies 3 and 9. 
Table 3. Mean bond distances, $d / \AA$, number of distances, $N$, and Debye-Waller coefficients, $\sigma^{2} / \AA^{2}$, in the EXAFS study of aqueous sodium selenate solutions and of solid sodium selenate salts at room temperature. The refinements were performed in the $k$ range $2-14 \AA^{-1} . F / \%$ is the goodness of fit as defined in the EXAFSPAK program.

\begin{tabular}{llllll}
\hline Species & Interaction & $N$ & $d$ & $\sigma^{2}$ & $F$
\end{tabular}

$0.50 \mathrm{~mol} \cdot \mathrm{dm}^{-3} \mathrm{NaHSeO}_{4}$ in water

\begin{tabular}{|c|c|c|c|c|}
\hline \multirow[t]{3}{*}{$\mathrm{HSeO}_{4}^{-}$} & $\mathrm{Se}-\mathrm{O}$ & 4 & $1.642(1)$ & $0.0027(1)$ \\
\hline & MS1 & 12 & $3.03(1)$ & $0.004(2)$ \\
\hline & $\mathrm{MS}\left(\mathrm{SeO}_{4}\right)^{\mathrm{a}}$ & $4+12$ & $3.33(3)$ & $0.012(2)$ \\
\hline
\end{tabular}

$0.50 \mathrm{~mol} \cdot \mathrm{dm}^{-3} \mathrm{Na}_{2} \mathrm{SeO}_{4}$ in water

$\begin{array}{llllll}\mathrm{SeO}_{4}{ }^{2-} & \mathrm{Se}-\mathrm{O} & 4 & 1.643(1) & 0.0020(1) & 11.1 \\ & \mathrm{MS1} & 12 & 3.01(2) & 0.008(2) \\ & \mathrm{MS}\left(\mathrm{SeO}_{4}\right)^{\mathrm{a}} & 4+12 & 3.32(3) & 0.008(3)\end{array}$

Solid $\mathrm{Na}_{2} \mathrm{SeO}_{4} \cdot 5 \mathrm{H}_{2} \mathrm{O}$

$\begin{array}{llllll}\mathrm{SeO}_{4}{ }^{2-} & \mathrm{Se}-\mathrm{O} & 4 & 1.644(1) & 0.0019(1) & 10.3 \\ \mathrm{MS} 1 & 12 & 3.05(2) & 0.007(2) \\ & \mathrm{MS}\left(\mathrm{SeO}_{4}\right)^{\mathrm{a}} & 4+12 & 3.43(2) & 0.005(2)\end{array}$

Solid $\mathrm{Na}_{2} \mathrm{SeO}_{4}$

$\begin{array}{llllll}\mathrm{SeO}_{4}{ }^{2-} & \mathrm{Se}-\mathrm{O} & 4 & 1.646(1) & 0.0017(1) & 10.8 \\ & \mathrm{MS} 1 & 12 & 2.99(1) & 0.006(2) \\ & \mathrm{MS}\left(\mathrm{SeO}_{4}\right)^{\mathrm{a}} & 4+12 & 3.296(9) & 0.004(1)\end{array}$

${ }^{\mathrm{a}}$ The multiple scattering of the selenite ion with tetrahedral geometry have two separate paths with double Se-O bond distance with the frequencies 4 and 12. 


\section{Legends to Figures}

Figure 1. LAXS, selenite ion. Top: the individual peak shapes for all contributing species in the $1.5006 \mathrm{~mol} \cdot \mathrm{dm}^{-3}$ aqueous solution of sodium selenite, the hydrated selenite ion (green line), hydrated sodium ion (purple line) and the aqueous bulk (orange line). (b) Experimental $D(r)$ $4 \pi r^{2} \rho_{\mathrm{o}}$ (red line); model (black line), the modelled distances are given in Table 2; difference (blue line). Bottom: reduced LAXS intensity function, $s i(s)$ (thin black line); model $s i_{\text {calc }}(s)$ (red line).

Figure 2. LAXS, selenate ion. Top: the individual peak shapes for all contributing species in the $1.5066 \mathrm{~mol} \cdot \mathrm{dm}^{-3}$ aqueous solution of sodium selenate. The hydrated selenate ion (green line), hydrated sodium ion (purple line) and the aqueous bulk (orange line). (b) Experimental $D(r)-$ $4 \pi r^{2} \rho_{\mathrm{o}}$ (red line); model (black line), the modelled distances are given in Table 2; difference (blue line). Bottom: reduced LAXS intensity function, $s i(s)$ (thin black line); model $s i_{\text {calc }}(s)$ (red line).

Figure 3. Upper: $k^{3}$ weighted EXAFS of (a) aqueous solution of selenous acid, (b) aqueous solution of sodium hydrogenselenite, (c) aqueous solution of sodium selenite, (d) solid sodium selenite. Lower: $k^{3}$ weighted EXAFS of (a) aqueous solution of sodium hydrogenselenate, (b) aqueous solution of sodium selenate, (c) solid sodium selenate decahydrate and (d) solid sodium selenate; experiment (thin black line); model (red line).

Figure 4. Upper: Fourier transform of the $k^{3}$ weighted EXAFS function of (a) aqueous solution of selenous acid, (b) aqueous solution of sodium hydrogenselenite, (c) aqueous solution of sodium selenite, (d) solid sodium selenite. Lower: Fourier transform of the $k^{3}$ weighted EXAFS function (a) aqueous solution of sodium hydrogenselenate, (b) aqueous solution of sodium 
selenate, (c) solid sodium selenate decahydrate and (d) solid sodium selenate; ; experiment (thin black line); model (red line).

Figure 5. Experimental XANES spectra of aqueous solutions of sodium selenite (black), sodium hydrogenselenate (red), selenous acid (blue), sodium selenate (green) and sodium hydrogenselenate (pink).

Figure 6. Double difference FTIR selenite ion. By PCA analysis using Gaussian peak shapes of the affected spectra. The analytical peaks could be found at the affected spectra (black) where $\mathrm{N}=15.7$, the anionic peaks brown and green at $2408 \pm 6$ and $2491 \pm 2$, where brown represents the asymmetric contributions. The sodium peak is represented by represents the red main peak at $2534 \pm 9$ and peak number blue at $2656 \pm 2$ which is well in agreement with earlier work. The tail at lower wavenumbers than 2300 is not associated with the O-D stretch of affected water.

Figure 7. Double difference FTIR $\mathrm{SeO}_{4}{ }^{2-}(\mathrm{aq})$. By PCA analysis using Gaussian peak shapes of the affected spectra. The analytical peaks could be found at the affected spectra (black) where $\mathrm{N}=12.9$, the anionic peaks green, purple and brown, where purple and brown represents the asymmetric contributions. For the sodium peak red represents the main peak which is well in agreement with earlier work and the blue is a asymmetric peak contribution. 
Figure 1
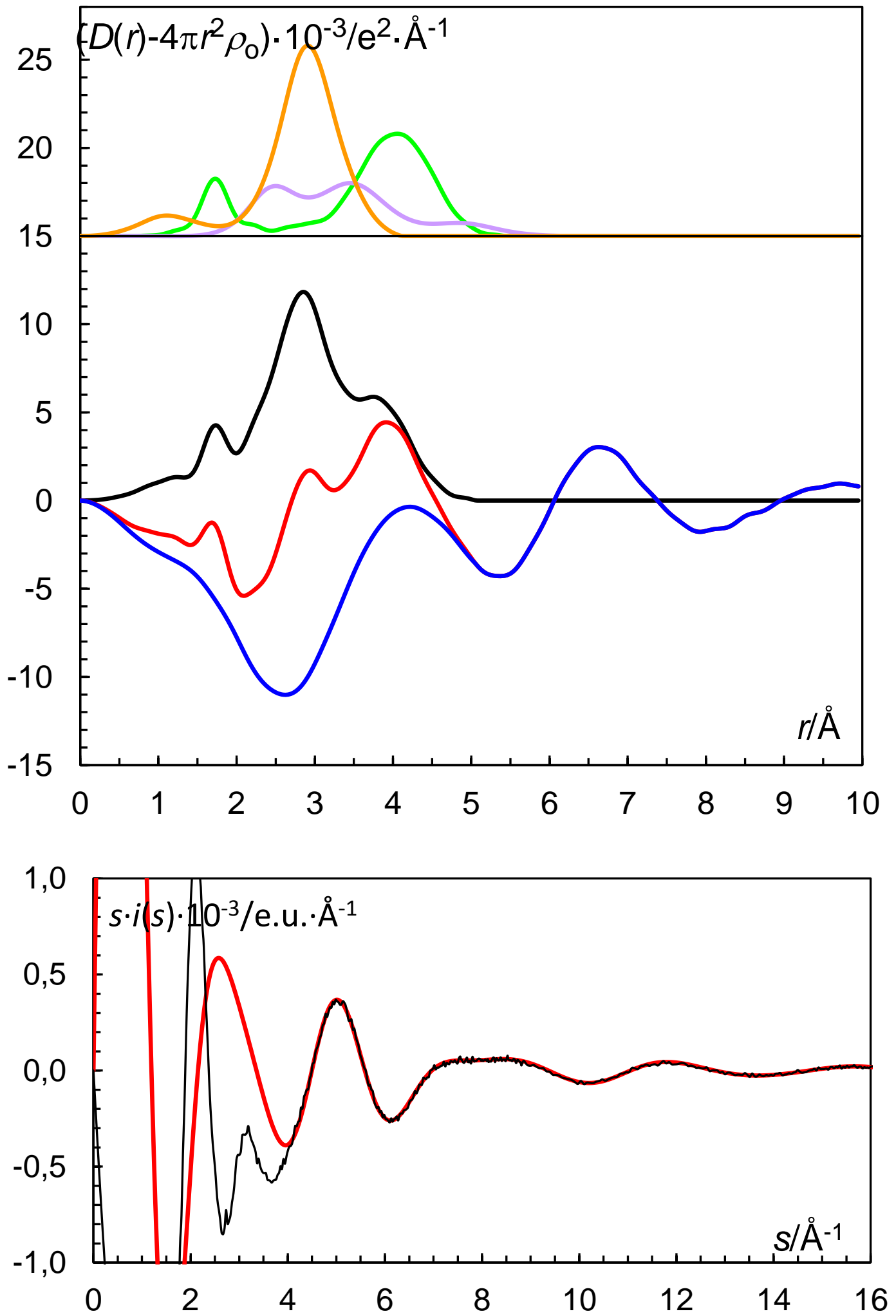
Figure 2
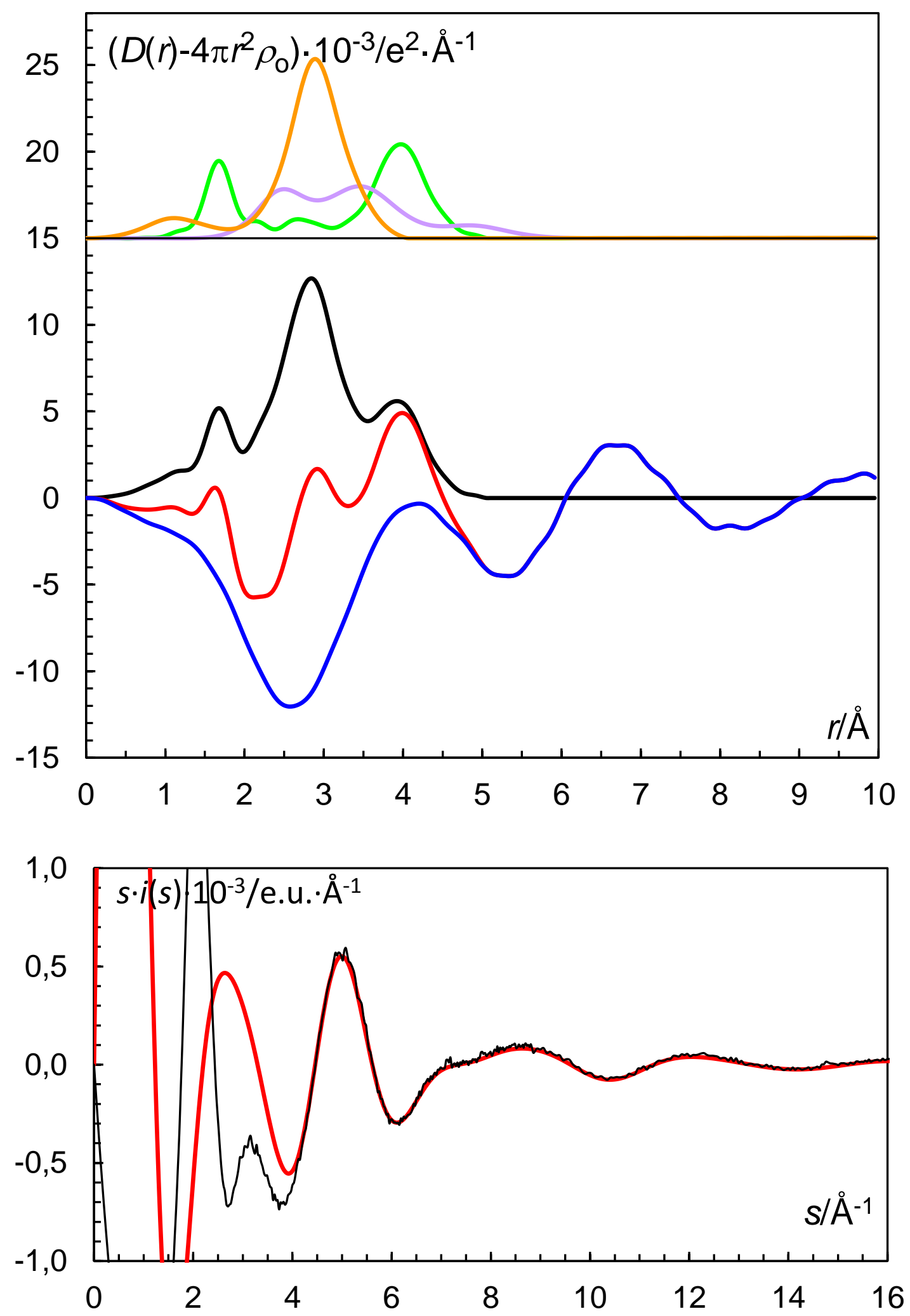
Figure 3
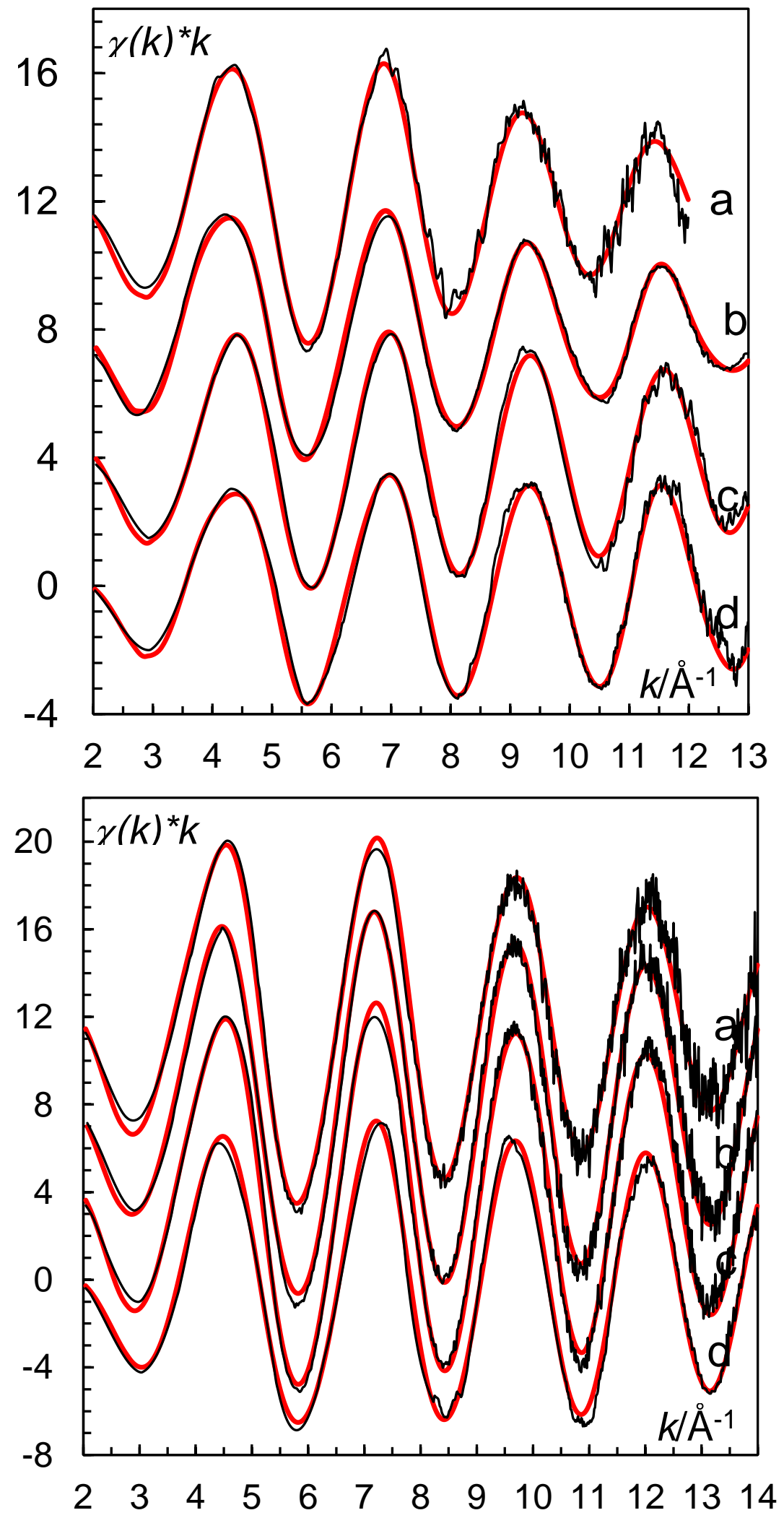
Figure 4
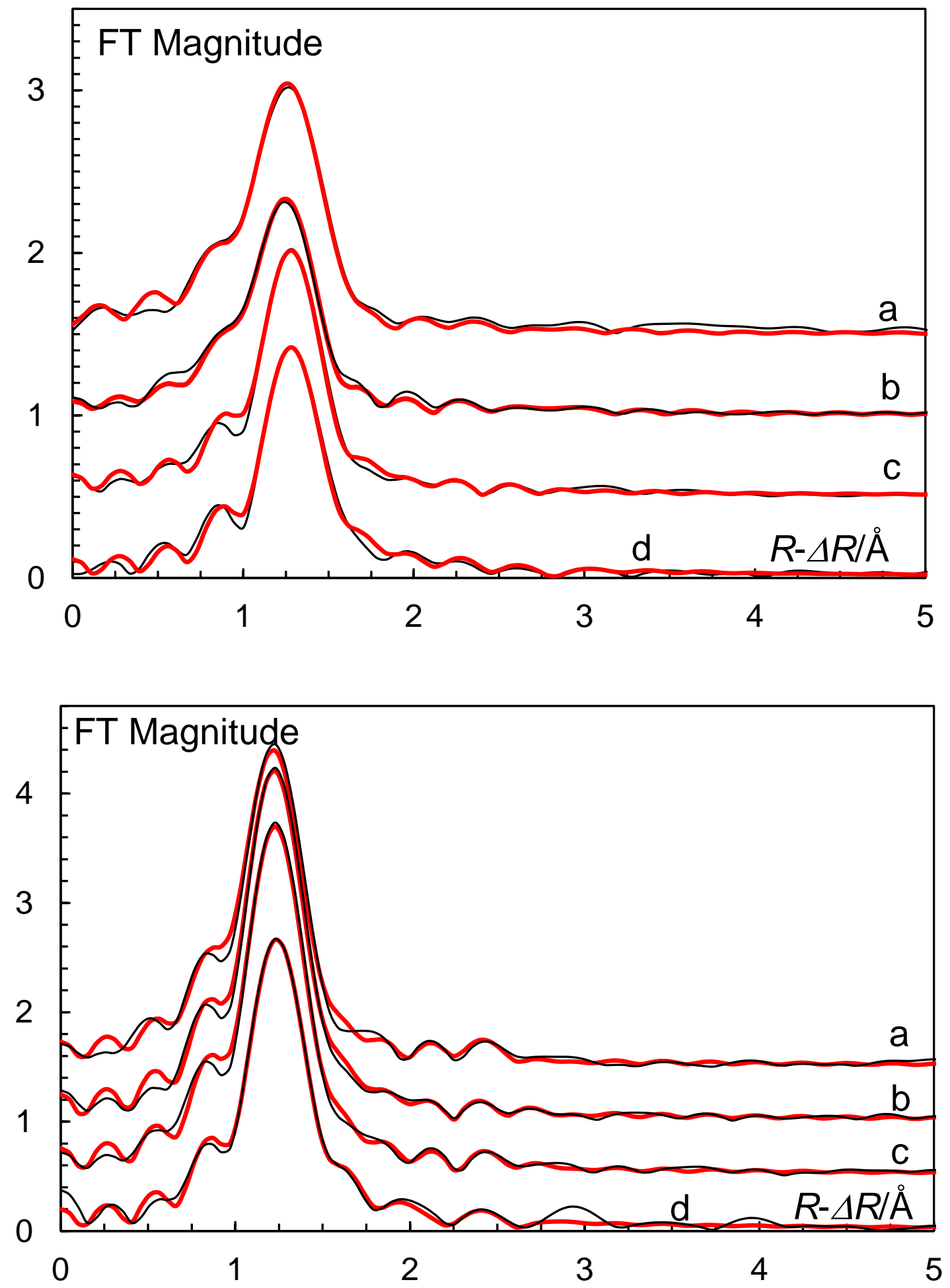
Figure 5.

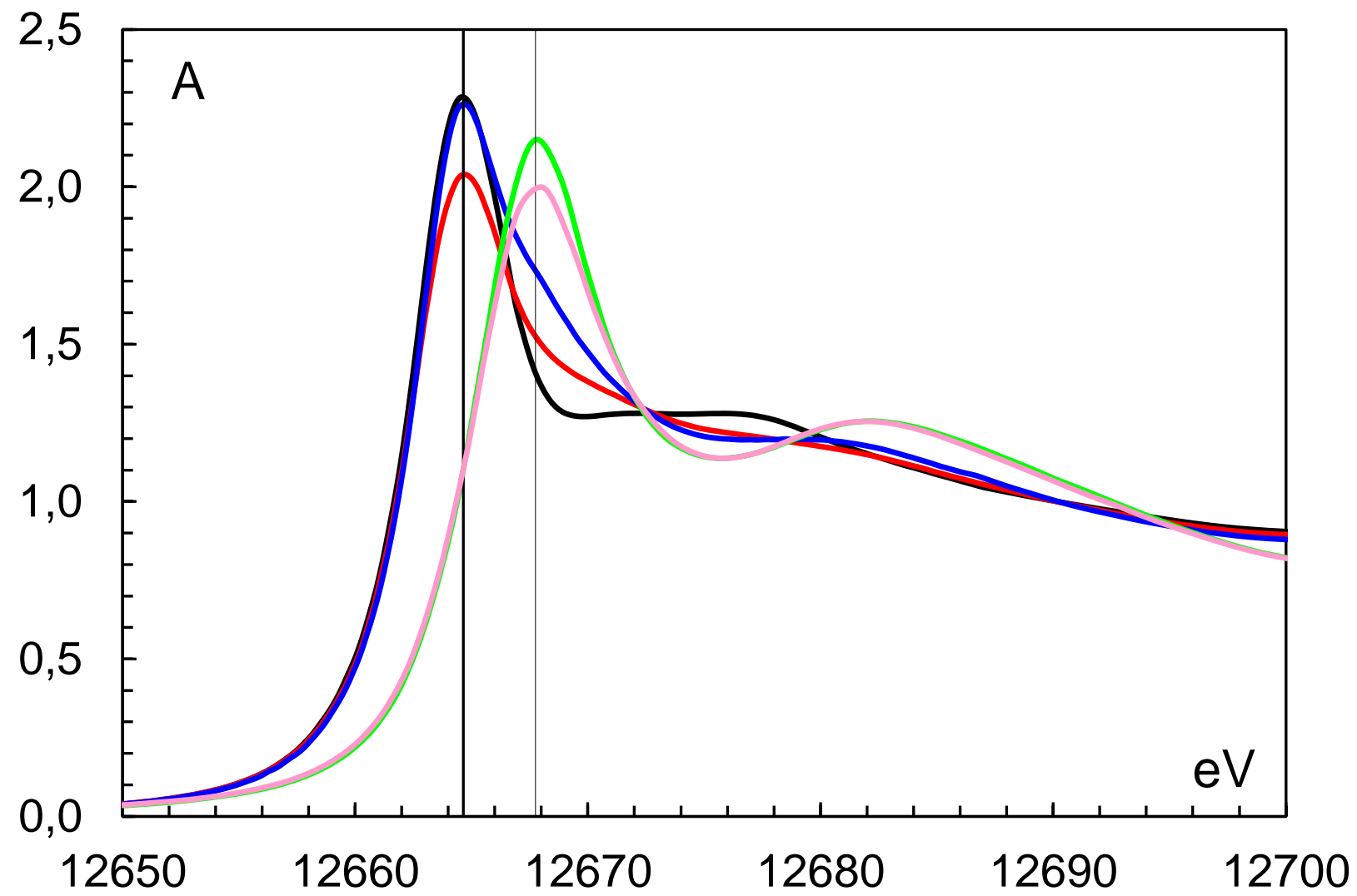


Figure 6.

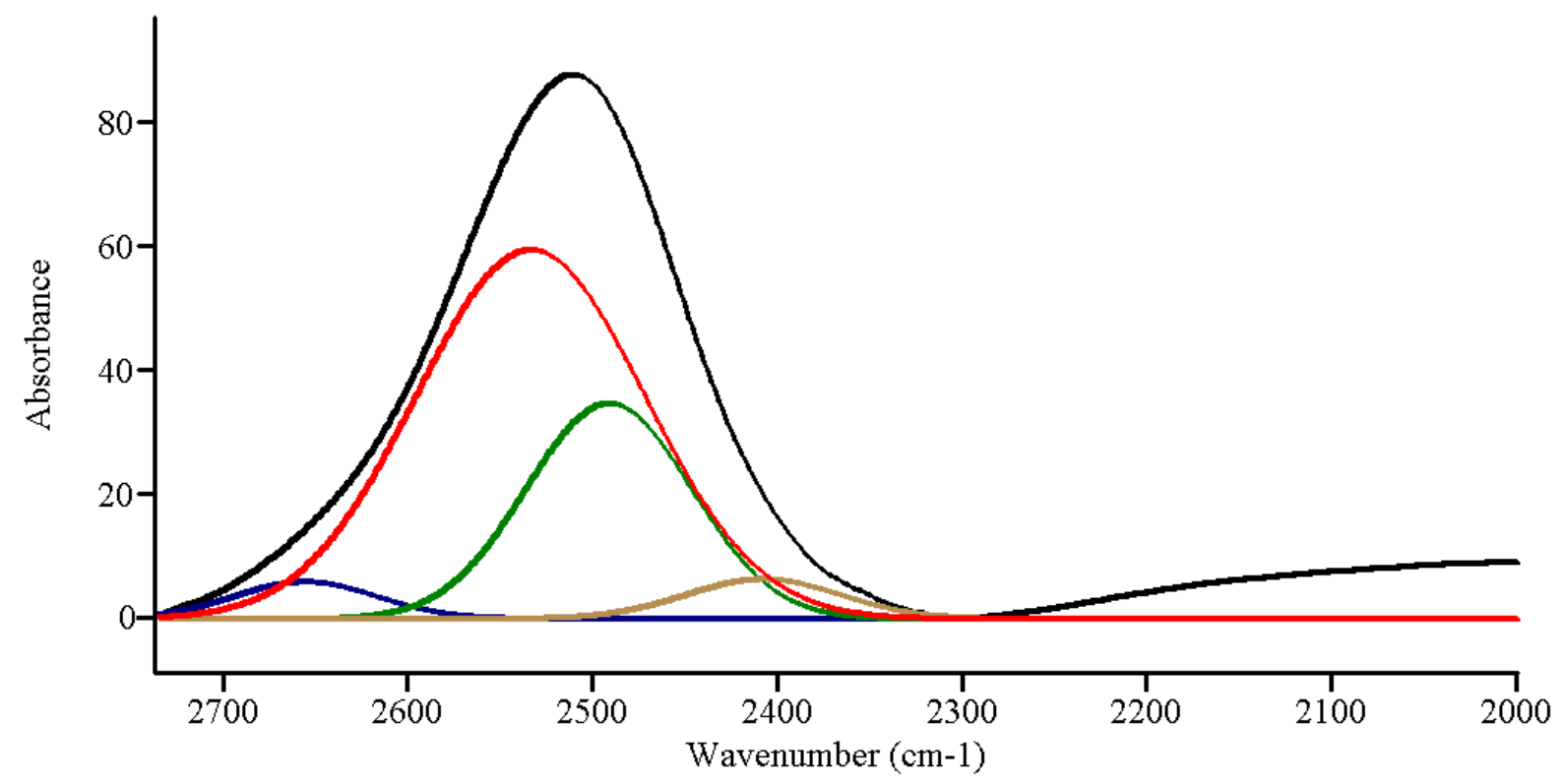

Figure 7.

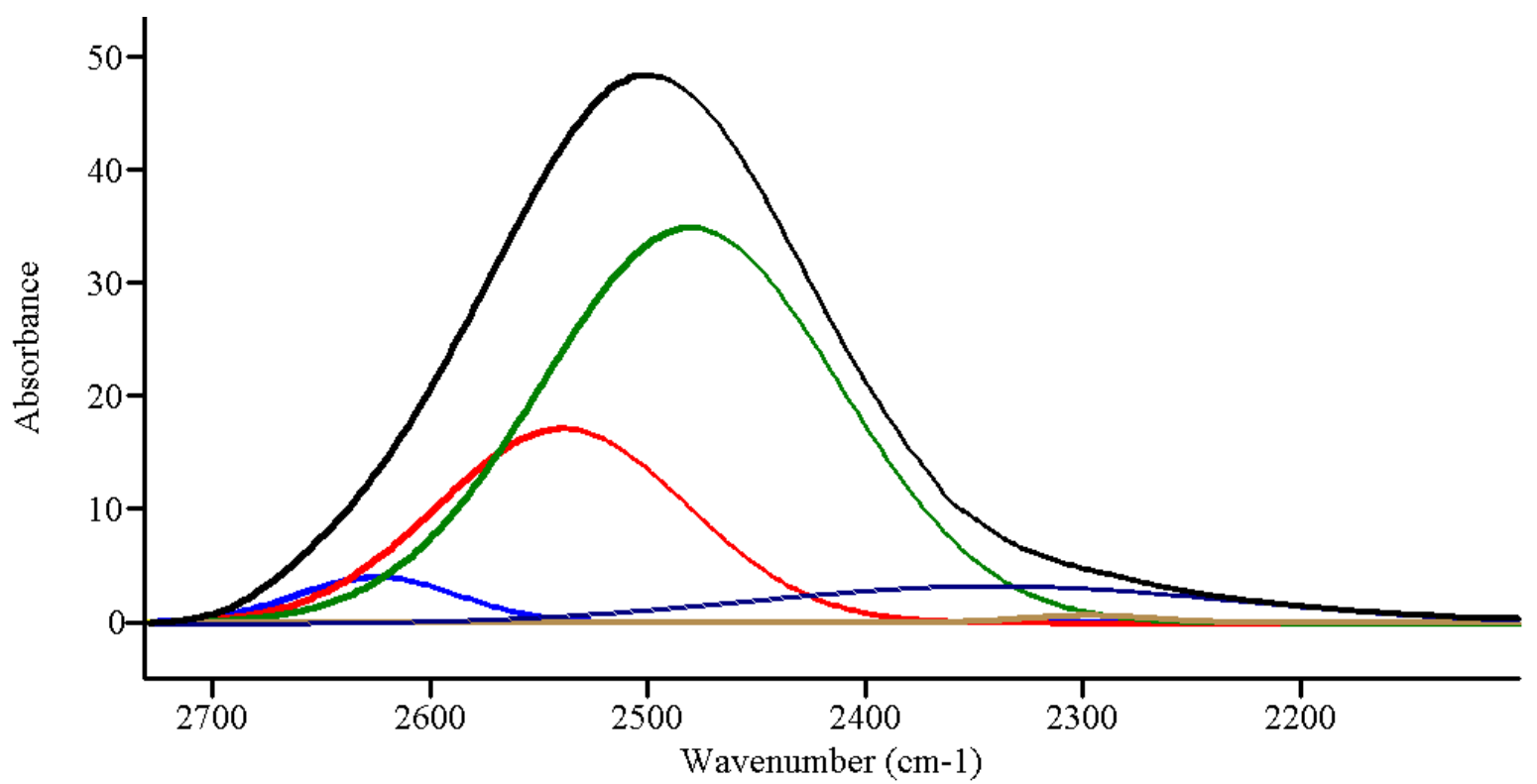


Structure and hydrogen bonding of the hydrated selenite and selenate ions in aqueous solution

\author{
Lars Eklund and Ingmar Persson*
}

Department of Chemistry and Biotechnology, Swedish University of Agricultural Sciences, P.O.Box 7015, SE-750 07 Uppsala, Sweden.

Supplementary Material 
Table S1. Concentrations $\left(\mathrm{mol} \cdot \mathrm{dm}^{-3}\right)$ of the aqueous selenite and selenate solutions used in the LAXS and EXAFS measurements; L denotes LAXS study and E EXAFS study.

\begin{tabular}{|c|c|c|c|c|c|c|c|}
\hline Sample & {$\left[\mathrm{SeO}_{\mathrm{x}}{ }^{2-}\right]$} & {$\left[\mathrm{Na}^{+}\right]$} & [water] & $\rho / \mathrm{g} \cdot \mathrm{cm}^{-3}$ & $\mu / \mathrm{cm}^{-1}$ & $\mathrm{pH}$ & Method \\
\hline $\mathrm{Na}_{2} \mathrm{SeO}_{3}$ in water & 1.5006 & 3.0012 & 49.207 & 1.170 & 10.27 & 12.0 & $\mathrm{~L}$ \\
\hline $\mathrm{Na}_{2} \mathrm{SeO}_{3}$ in water & 0.500 & 1.000 & & & & 12.0 & $\mathrm{E}$ \\
\hline $\mathrm{NaHSeO}_{3}$ in water & 0.500 & 0.500 & & & & 5.0 & $\mathrm{E}$ \\
\hline $\mathrm{H}_{2} \mathrm{SeO}_{3}$ in water & 0.500 & & & & & 1.0 & $\mathrm{E}$ \\
\hline $\mathrm{Na}_{2} \mathrm{SeO}_{4}$ in water & 1.5066 & 3.0132 & 50.277 & 1.190 & 10.33 & 12.0 & $\mathrm{~L}$ \\
\hline $\mathrm{Na}_{2} \mathrm{SeO}_{4}$ in water & 0.500 & 1.000 & & & & 12.0 & $\mathrm{E}$ \\
\hline $\mathrm{NaHSeO}_{4}$ in water & 0.500 & 0.500 & & & & 1.0 & $\mathrm{E}$ \\
\hline
\end{tabular}


Table S2. Summary of Se-O bond distances solid state structures of selenite ion, hydrogenselenite ion, selenous acid, selenate ion, hydrogenselenate ion and selenic acid from the Inorganic Crystal Structure Database (ICSD) and Cambridge Structure Database (CSD). References in red are not included in the average value.

\begin{tabular}{|c|c|}
\hline \multicolumn{2}{|l|}{ ICSD/ } \\
\hline CSD code & $d(\mathrm{Se}-\mathrm{O}) / A$ \\
\hline \multicolumn{2}{|c|}{ Selenite ion, $\mathrm{SeO}_{3}{ }^{2-}$} \\
\hline VEXCAD & $1.676 \AA ̊ ̊$ \\
\hline TUYMOP & $1.686 \AA$ \\
\hline YASHAC & $1.687 \AA$ \\
\hline BAYBUZ & $1.689 \AA$ \\
\hline 420179 & $1.691 \AA$ \\
\hline BAYCEK & $1.692 \AA$ \\
\hline 167531 & $1.692 \AA$ \\
\hline 280981 & $1.698 \AA$ \\
\hline VEXCEH & $1.698 \AA$ \\
\hline 184743 & $1.698 \AA$ \\
\hline 184742 & $1.700 \AA$ \\
\hline BAYCIO & $1.700 \AA$ \\
\hline 184744 & $1.701 \AA$ \\
\hline 167530 & 1.710 \\
\hline
\end{tabular}

\section{Reference Formula of compound}

Wiechoczek, M.; Jones, P. G. Z. Naturforsch., Teil B 2006, 61, 1401. $\left(\mathrm{C}_{4} \mathrm{H}_{12} \mathrm{~N}\right)_{2}\left(\mathrm{SeO}_{3}\right)$

Havlicek, D.; Chudoba, V.; Nemec, I.; Cisarova, I.; Micka, Z. J. Mol. Struct. 2002, 606, 101. $\left(\mathrm{C}_{4} \mathrm{H}_{12} \mathrm{~N}_{2}\right)\left(\mathrm{SeO}_{3}\right) \cdot \mathrm{H}_{2} \mathrm{O}$

Todd, M. J.; Harrison, W. T. A. Acta Crystallogr., Sect. E 2005, 61, o1538. $\left(\mathrm{C}_{3} \mathrm{H}_{12} \mathrm{~N}_{2}\right)\left(\mathrm{SeO}_{3}\right) \cdot \mathrm{H}_{2} \mathrm{O}$ Chudoba, V.; Micka, Z.; Havlicek, D.; Cisarova, I.; Nemec, I.; Robinson, W. T. J. Solid State Chem. 2003, 170, 390. $\left(\mathrm{C}_{4} \mathrm{H}_{14} \mathrm{~N}_{2}\right)\left(\mathrm{SeO}_{3}\right) \cdot \mathrm{H}_{2} \mathrm{O}$

Burns, W. L.; Ibers, J. A. J. Solid State Chem. 2009, 182, 1457-1461. Cs $\left(\mathrm{UO}_{2}\right)\left(\mathrm{SeO}_{3}\right)\left(\mathrm{HSeO}_{3}\right) \cdot 3 \mathrm{H}_{2} \mathrm{O}$ Chudoba, V.; Micka, Z.; Havlicek, D.; Cisarova, I.; Nemec, I.; Robinson, W. T. J. Solid State Chem. 2003, 170, 390. $\left(\mathrm{C}_{3} \mathrm{H}_{12} \mathrm{~N}_{2}\right)\left(\mathrm{SeO}_{3}\right) \cdot 2 \mathrm{H}_{2} \mathrm{O}$

Chang Hong Young; Kim Sun Woo; Shiv Halasyamani, P. Chem. Mat. 2010, 22, 3241-3250.

$\mathrm{Tl}_{2}\left(\mathrm{MoO}_{3}\right)_{3} \mathrm{SeO}_{3}$

Wickleder, M. S. Acta Crystallogr., Sect. E 2002, 58, 103-104. $\mathrm{Na}_{2} \mathrm{SeO}_{3}$

Wiechoczek, M.; Jones, P. G. Z. Naturforsch., Teil B 2006, 61, 1401. $\left(\mathrm{C}_{4} \mathrm{H}_{12} \mathrm{~N}\right)_{2}\left(\mathrm{SeO}_{3}\right) \cdot 1.5 \mathrm{H}_{2} \mathrm{O}$

Kong Fang; Hu Chunli; Xu Xiang; Zhou Tianhua; Mao Jianggao Dalton Trans. 2012, 41, 5687-5695. $\mathrm{Rb}_{4} \mathrm{Mo}_{5} \mathrm{O}_{15}\left(\mathrm{SeO}_{3}\right)_{2}\left(\mathrm{H}_{2} \mathrm{O}\right)_{2}$

Kong Fang; Hu Chunli; Xu Xiang; Zhou Tianhua; Mao Jianggao Dalton Trans. 2012, 41, 5687-5695. $\mathrm{K}_{4} \mathrm{Mo}_{5} \mathrm{O}_{15}\left(\mathrm{SeO}_{3}\right)_{2}\left(\mathrm{H}_{2} \mathrm{O}\right)_{2}$

Chudoba, V.; Micka, Z.; Havlicek, D.; Cisarova, I.; Nemec, I.; Robinson, W. T. J. Solid State Chem. 2003, 170, 390. $\left(\mathrm{C}_{2} \mathrm{H}_{10} \mathrm{~N}_{2}\right)\left(\mathrm{SeO}_{3}\right)$

Kong Fang; Hu Chunli; Xu Xiang; Zhou Tianhua; Mao Jianggao Dalton Trans. 2012, 41, 5687-5695. $\mathrm{Rb}_{4} \mathrm{Mo}_{5} \mathrm{O}_{15}\left(\mathrm{SeO}_{3}\right)_{2}\left(\mathrm{H}_{2} \mathrm{O}\right)_{2}$

Chang Hong Young; Kim Sun Woo; Shiv Halasyamani, P. Chem. Mat. 2010, 22, 3241-3250. 


\section{Mean 1.691 Å/9}

$\mathrm{Rb}_{2}\left(\mathrm{MoO}_{3}\right)_{3} \mathrm{SeO}_{3}$

\section{Hydrogenselenite ion, $\mathrm{HSeO}_{3}^{-}$}

ZOKZEE $\quad 1.640+1.760 \AA$ ̊ de Matos Gomes, E.; Matos Beja, A.; Paixao, J. A.; de Veiga, L. A.; Ramos Silva, M.; Martin-Gil, J.; Martin-Gil, F. J. Z. Kristallogr. 1995, 210, 929. $\left(\mathrm{C}_{10} \mathrm{H}_{16} \mathrm{~N}\right)\left(\mathrm{HSeO}_{3}\right) \cdot \mathrm{H}_{2} \mathrm{SeO}_{3}$

WAGVOR $1.650+1.719 \AA$ Huili Chen, Wei Gao, Miaoli Zhu, Hongfei Gao, Jinfang Xue, Yingqi Li Chem.Commun. 2010, 46, 8389.

XUJDUB $\quad 1.652+1.787 \AA \quad$ Lukevics, E.; Arsenyan, P.; Shestakova, I.; Domracheva, I.; Kanepe, I.; Belyakov, S.; Popelis, J.; Pudova, O. Appl. Organomet. Chem. 2002, 16, 228. $\left(\mathrm{C}_{6} \mathrm{H}_{16} \mathrm{NO}_{3}\right)\left(\mathrm{HSeO}_{3}\right)$

202718 1.653+1.801 Å Micka, Z.; Danek, M.; Loub, J.; Strauch, B.; Podlahova, J.; Hasek, J. J. Solid State Chem. 1988, 77, 306-315. $\mathrm{Cs}\left(\mathrm{HSeO}_{3}\right)$

ADAVAC 1.654+1.791 ^ de Matos Gomes, E.; Nogueira, E.; Fernandes, I.; Belsley, M.; Paixao, J. A.; Matos Beja, A.; Ramos Silva, M.; Martin-Gil, J.; Martin-Gil, F.; Mano, J. F. Acta Crystallogr., Sect. B 2001, $57,828$. $\left(\mathrm{C}_{6} \mathrm{H}_{15} \mathrm{~N}_{4} \mathrm{O}_{2}\right)\left(\mathrm{HSeO}_{3}\right) \cdot 0.15 \mathrm{H}_{2} \mathrm{O}$

1.657+1.757 ̊̊ Loub, J.; Micka, Z.; Podlahova, J.; Maly, K.; Kopf, J. Coll. Czech. Chem. Commun. 1992, 57, 23092314. $\mathrm{Na}\left(\mathrm{HSeO}_{4}\right) \cdot 3 \mathrm{H}_{2} \mathrm{SeO}_{3}$

RESNEI $\quad 1.657+1.768$ A Paixao, J. A.; Matos Beja, A.; Ramos Silva, M.; de Matos Gomes, E.; Martin-Gil, J.; Martin-Gil, F. J. Acta Crystallogr., Sect. C 1997, 53, 1113. $\left(\mathrm{C}_{13} \mathrm{H}_{14} \mathrm{~N}_{3}\right)\left(\mathrm{HSeO}_{3}\right) \cdot \mathrm{H}_{2} \mathrm{O}$

JIVWEQ $\quad 1.658+1.784 \AA \quad$ Nemec, I.; Cisarova, I.; Micka, Z. J. Solid State Chem. 1998, 140, 71. $\left(\mathrm{C}_{2} \mathrm{H}_{6} \mathrm{NO}_{2}\right)\left(\mathrm{HSeO}_{3}\right) \cdot \mathrm{C}_{2} \mathrm{H}_{5} \mathrm{NO}_{2}$

$8255 \quad 1.659+1.791 \AA$ Chomnilpan, S.; Liminga, R. Acta Crystallogr., Sect. B 1979, 35, 3011-3013. Li( $\left.\mathrm{HSeO}_{3}\right)$

$202266 \quad 1.659+1.783 \AA$ Hiltunen, L.; Holsa, J.; Micka, Z. J. Solid State Chem. 1987, 68, 307-313. $\mathrm{Cs}\left(\mathrm{HSeO}_{4}\right) \cdot 2 \mathrm{H}_{2} \mathrm{SeO}_{3}$

DEHQOX $\quad 1.659+1.758 \AA \quad$ Jun-Jieh Wang; Tessier, C. T.; Holm, R. H. Inorg. Chem. 2006, 45, 2979. $\left(\mathrm{C}_{8} \mathrm{H}_{20} \mathrm{~N}\right)\left(\mathrm{HSeO}_{3}\right)$

XORBUB $\quad 1.659+1.769 \AA$ Nemec, I. Chudoba, V.; Havlicek, D.; Cisarova, I.; Micka, Z. J. Solid State Chem. 2001, 161, 312. $\left(\mathrm{C}_{6} \mathrm{H}_{16} \mathrm{~N}_{2}\right)\left(\mathrm{HSeO}_{3}\right)_{2}$

$403078 \quad 1.660+1.782 \AA \quad$ Eichhorn, K. D.; Kek, S. Z. Kristallogr. 1997, 212, 724-731. $\mathrm{Li}\left(\mathrm{HSeO}_{3}\right)$

EKIBAB $\quad 1.667+1.763 \AA$ Ritchie, L. K.; Harrison, W. T. A. Acta Crystallogr., Sect. E 2001, 59, o1296. $\left(\mathrm{C}_{2} \mathrm{H}_{7} \mathrm{~N}_{4} \mathrm{O}\right)\left(\mathrm{HSeO}_{3}\right)$

CADMAX 1.667+1.778 ̊ Gharzaryan, V. V.; Fleck, M.; Petrosyan, A. M. Proc. of SPIE - Int. Conf. Las. Phys. 2011, 7998, 
79980F.

\begin{tabular}{|c|c|c|}
\hline KELKAO & $668+1.765 \AA$ & $\begin{array}{l}\text { Paixao, J. A.; Silva, M. R.; Beja, A. M.; Eusebio, E. Polyhedron 2006, 25, } 2021 . \\
\left(\mathrm{C}_{11} \mathrm{H}_{13} \mathrm{~N}_{2} \mathrm{O}_{2}\right)\left(\mathrm{HSeO}_{3}\right)\end{array}$ \\
\hline 250286 & $1.670+1.749 \AA$ & $\begin{array}{l}\text { Krivovichev, S. V.; Tananaev, I. G.; Kahlenberg, V.; Myasoedov, B. F. Dokl. Akad. Nauk 2005, 403, } \\
\text { 349-352. }\left(\left(\mathrm{C}_{5} \mathrm{H}_{11}\right) \mathrm{NH}_{3}\right)\left(\mathrm{UO}_{2}\right)\left(\mathrm{SeO}_{4}\right)\left(\mathrm{HSeO}_{3}\right)\end{array}$ \\
\hline 62335 & $1.671+1.781 \AA$ & $\begin{array}{l}\text { Bannova, I. I.; Vinogradova, I. S.; Kuz'min, A. M.; Rozhdestvenskaya, I. V.; Usov, O. A. } \\
\text { Kristallografiya 1987, 32N, 83-85. } \mathrm{Rb}\left(\mathrm{HSeO}_{3}\right)\end{array}$ \\
\hline 171372 & $1.672+1.761 \AA$ & Weil, M. Acta Crystallogr., Sect. E 2006, 62, i38-i40. $\mathrm{NH}_{4}\left(\mathrm{HSeO}_{3}\right)$ \\
\hline 62289 & $1.676+1.750 \AA$ & 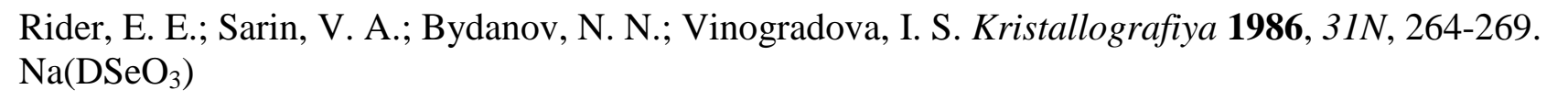 \\
\hline 62288 & $1.679+1.746 \AA$ & $\begin{array}{l}\text { Rider, E. E.; Sarin, V. A.; Bydanov, N. N.; Vinogradova, I. S. Kristallografiya 1986, 31N, 264-269. } \\
\mathrm{Na}\left(\mathrm{HSeO}_{3}\right)\end{array}$ \\
\hline 420179 & $1.679+1.767 \AA$ & Burns, W. L.; Ibers, J. A. J. Solid State Chem. 2009, 182, 1457-1461. Cs $\left(\mathrm{UO}_{2}\right)\left(\mathrm{SeO}_{3}\right)\left(\mathrm{HSeO}_{3}\right) \cdot 3 \mathrm{H}_{2} \mathrm{O}$ \\
\hline KELKAO01 & $1.679+1.763 \AA$ & $\begin{array}{l}\text { Paixao, J. A.; Silva, M. R.; Beja, A. M.; Eusebio, E. Polyhedron 2006, 25, } 2021 . \\
\left(\mathrm{C}_{11} \mathrm{H}_{13} \mathrm{~N}_{2} \mathrm{O}_{2}\right)\left(\mathrm{HSeO}_{3}\right)\end{array}$ \\
\hline
\end{tabular}

Mean $\quad 1.663+1.768 \AA / 23 \quad$ (Mean $1.698 \AA ⿱ 2023)$

Selenous acid, $\mathrm{H}_{2} \mathrm{SeO}_{3}$

ZOKZEE $\quad 1.612+1.739 \AA$ A de Matos Gomes, E.; Matos Beja, A.; Paixao, J. A.; de Veiga, L. A.; Ramos Silva, M.; Martin-Gil, J.; Martin-Gil, F. J. Z. Kristallogr. 1995, 210, 929. $\left(\mathrm{C}_{10} \mathrm{H}_{16} \mathrm{~N}\right)\left(\mathrm{HSeO}_{3}\right) \cdot \mathrm{H}_{2} \mathrm{SeO}_{3}$

73332 1.618+1.735 ̊̊ Loub, J.; Micka, Z.; Podlahova, J.; Maly, K.; Kopf, J. Coll. Czech. Chem. Commun. 1992, 57, 23092314. $\mathrm{Na}\left(\mathrm{HSeO}_{4}\right) \cdot 3 \mathrm{H}_{2} \mathrm{SeO}_{3}$

NIRSIQ $\quad 1.622+1.735 \AA$ A Paixao, J. A.; Matos Beja, A.; Ramos Silva, M.; Alte da Veiga, L.; Martin-Gil, J.; Martin-Gil, F.; de Matos Gomes, E. Z. Kristallogr. - New Cryst. Struct. 1997, 212, 51. $\mathrm{C}_{5} \mathrm{H}_{11} \mathrm{NO}_{2} \cdot \mathrm{H}_{2} \mathrm{SeO}_{3}$

$202266 \quad 1.632+1.748 \AA$ Hiltunen, L.; Holsa, J.; Micka, Z. J. Solid State Chem. 1987, 68, 307-313. $\mathrm{Cs}_{2}\left(\mathrm{HSeO}_{4}\right) \cdot 2 \mathrm{H}_{2} \mathrm{SeO} 3$

$717861.666+1.740 \AA$ Aaran, J.; Lis, T.; Marchewka, M.; Ratajczak, H. J. Mol. Struct. 1991, 250, 13-45. $\mathrm{Na}_{2} \mathrm{SeO}_{4} \cdot \mathrm{H}_{2} \mathrm{SeO}_{3}$

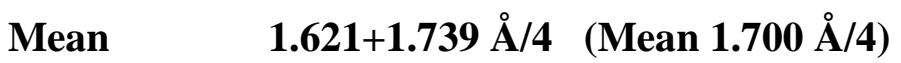




$\begin{array}{lc}\text { Selenate ion, } \mathrm{SeO}_{4}{ }^{2-} \\ 73411 & 1.600 \AA \\ \text { OKOKUV01 } & 1.608 \AA \\ \text { OKOKUV } & 1.612 \AA \\ \text { WULSAY03 } & 1.615 \AA \\ 419775 & 1.617 \AA \\ 99382 & 1.618 \AA \\ 21047 & 1.620 \AA \\ 157371 & 1.620 \AA \\ 419338 & 1.621 \AA \\ 14298 & 1.622 \AA \\ 107620 & 1.622 \AA \\ 200539 & 1.622 \AA \\ 73464 & 1.624 \AA \\ 81688 & 1.624 \AA \\ 99383 & 1.625 \AA \\ 81689 & \\ & \\ & \\ & \\ & \\ & \\ & \\ & \end{array}$

Fabry, J.; Breczewski, T. Acta Crystallogr., Sect. C 1993, 49, 1724-1727. $\mathrm{Tl}_{2} \mathrm{SeO}_{4}$ Custelcean, R.; Bock, A.; Moyer, B. A. J. Am. Chem. Soc. 2010, 132, 7177.

Custelcean, R.; Bock, A.; Moyer, B. A. J. Am. Chem. Soc. 2010, 132, 7177.

Wen Zhang; Li-Zhuang Chen; Ren-Gen Xiong; Nakamura; T.; Huang, S. D. J. Am. Chem. Soc. 2009, 131, 12544.

Grzechnik, A.; Breczewski, T.; Friese, K. J. Solid State Chem. 2008, 181, 2914-2917. $\mathrm{Tl}_{2} \mathrm{SeO}_{4}$

Friese, K.; Goeta, A. E.; Leech, M. A.; Howard, J. A. K.; Madariaga, G.; Perez-Mato, J. M.;

Breczewski, T. J. Solid State Chem. 2004, 177, 1127-1136. $\mathrm{Tl}_{2} \mathrm{SeO}_{4}$

Kruglik, A. I.; Simonov, V. I.; Yuzvak, V. I. Kristallografiya 1973, 18N, 287-292.

$\left(\mathrm{NH}_{4}\right) \mathrm{NaSeO}_{4} \cdot 2 \mathrm{H}_{2} \mathrm{O}$

Dammak, M.; Litaiem, H.; Gravereau, P.; Mhiri, T.; Kolsi, A. W. J. Alloys Compd. 2007, 442, 316319. $\mathrm{Rb}_{2} \mathrm{SeO}_{4} \cdot \mathrm{Te}(\mathrm{OH})_{6}$

Ghedia, S.; Dinnebier, R.; Jansen, M. Solid State Sci. 2009, 11, 72-76. $\mathrm{Rb}_{2} \mathrm{SeO}_{4}$

Kalman, A.; Stephens, J. S.; Cruickshank, D. W. J. Acta Crystallogr., Sect. B 1970, 26, 1451-1454. $\mathrm{K}_{2} \mathrm{SeO}_{4}$

Malchus, M.; Jansen, M. Z. Naturforsch., Teil B 1998, 53, 704-710. $\left.\left(\mathrm{N}_{(\mathrm{CH}}\right)_{4}\right)_{2} \mathrm{SeO}_{4}$

Nozik, Y. Z.; Fykin, L. E.; Duderov, V. Y.; Muradyan, L. A.; Rostuntseva, A. I. Kristallografiya 1978, $23 N, 617-619 . \mathrm{Na}\left(\mathrm{NH}_{4}\right) \mathrm{SeO}_{4} \cdot 2 \mathrm{H}_{2} \mathrm{O}$

Fabry, J.; Breczewski, T.; Petricek, V. Acta Crystallogr., Sect. B 1993, 49, 826-832. $\mathrm{K}_{3} \mathrm{Na}\left(\mathrm{SeO}_{4}\right)_{2}$

Gonzalez-Silgo, C.; Solans, X.; Ruiz-Perez, C.; Martinez-Sarrion, M. L.; Mestres, L. Ferroelectrics 1996, 177, 191-199. $\mathrm{K}_{2} \mathrm{SeO}_{4}$

Friese, K.; Goeta, A. E.; Leech, M. A.; Howard, J. A. K.; Madariaga, G.; Perez-Mato, J. M.; Breczewski, T. J. Solid State Chem. 2004, 177, 1127-1136. $\mathrm{Tl}_{2} \mathrm{SeO}_{4}$

Gonzalez-Silgo, C.; Solans, X.; Ruiz-Perez, C.; Martinez-Sarrion, M. L.; Mestres, L. Ferroelectrics 1996, 177, 191-199. $\mathrm{K}_{2} \mathrm{SeO}_{4}$

Gonzalez-Silgo, C.; Solans, X.; Ruiz-Perez, C.; Martinez-Sarrion, M. L.; Mestres, L. Ferroelectrics 1996, 177, 191-199. $\mathrm{K}_{2} \mathrm{SeO}_{4}$ 


\begin{tabular}{|c|c|c|}
\hline LORYAT & $1.626 \AA$ & Janczak, J.; Perpetuo, G. J. Acta Crystallogr., Sect. E 2009, 65, o121. \\
\hline 54168 & $1.627 \AA$ & Fukami, T.; Chen, R.-H. Acta Phys. Pol., Ser. A 1998, 94, 795-801. $\mathrm{K}_{3} \mathrm{Na}\left(\mathrm{SeO}_{4}\right)_{2}$ \\
\hline WULSAY01 & $1.627 \AA$ & $\begin{array}{l}\text { Wen Zhang; Li-Zhuang Chen; Ren-Gen Xiong; Nakamura; T.; Huang, S. D. J. Am. Chem. Soc. 2009, } \\
\text { 131, } 12544 .\end{array}$ \\
\hline 158790 & $1.628 \AA$ & Krivovichev, S. V. Ukrain. Dokl. Kristallogr. 2006, 135, 106-113. $\left[\mathrm{Al}\left(\mathrm{H}_{2} \mathrm{O}\right)_{6}\right]_{2}\left(\mathrm{SeO}_{4}\right)_{3}\left(\mathrm{NO}_{3}\right) \cdot 4 \mathrm{H}_{2} \mathrm{O}$ \\
\hline 250316 & $1.628 \AA$ & $\begin{array}{l}\text { Krivovichev, S. V. Zapiski Vserossijskogo Mineralogicheskogo Obshchestva 2006, 135, 106-113. } \\
{\left[\mathrm{Al}\left(\mathrm{H}_{2} \mathrm{O}\right)_{6}\right]_{2}\left(\mathrm{SeO}_{4}\right)_{3} \cdot 4 \mathrm{H}_{2} \mathrm{O}}\end{array}$ \\
\hline 419776 & $1.628 \AA$ & Grzechnik, A.; Breczewski, T.; Friese, K. J. Solid State Chem. 2008, 181, 2914-2917. $\mathrm{Tl}_{2} \mathrm{SeO}_{4}$ \\
\hline 81691 & $1.630 \AA$ & $\begin{array}{l}\text { Gonzalez-Silgo, C.; Solans, X.; Ruiz-Perez, C.; Martinez-Sarrion, M. L.; Mestres, L. Ferroelectrics } \\
\text { 1996, 177, 191-199. } \mathrm{K}_{2} \mathrm{SeO}_{4}\end{array}$ \\
\hline 94517 & $1.630 \AA$ & $\begin{array}{l}\text { Troyanov, S. I.; Kosterina, E. V.; Kemnitz, E. Zh. Neorg. Khim. 2001, 46, 1496-1502. } \\
\mathrm{Cs}_{4}\left(\mathrm{SeO}_{4}\right)\left(\mathrm{HSeO}_{4}\right)_{2} \cdot \mathrm{HF}\end{array}$ \\
\hline 160681 & $1.630 \AA$ & $\begin{array}{l}\text { Smirnov, L. S.; Melnyk, G.; Zink, N.; Wozniak, K.; Dominiak, P.; Pawlukojc, A.; Loose, A.; } \\
\text { Shuvalov, L. A. Poverkhnostnye Fizika, Khimiya, Mekhanika 2007, 73-79. }\left(\mathrm{NH}_{4}\right)_{2}\left(\mathrm{SeO}_{4}\right)_{2}\end{array}$ \\
\hline 281276 & $1.630 \AA$ & Johnston, M. G.; Harrison, W. T. A. Acta Crystallogr., Sect. E 2003, 59, i25-i27. $\mathrm{Li}_{2} \mathrm{SeO}_{4} \cdot \mathrm{H}_{2} \mathrm{O}$ \\
\hline 710013 & $1.630 \AA$ & $\begin{array}{l}\text { Euler, H.; Barbier, B.; Meents, A.; Kirfel, A. Z. Kristallogr. - New Crystal Struct. 2009, 224, 360-364. } \\
\mathrm{Tl}_{2}\left[\mathrm{Zn}\left(\mathrm{H}_{2} \mathrm{O}\right)_{6}\right]\left(\mathrm{SeO}_{4}\right)_{2}\end{array}$ \\
\hline RUXWIQ & $1.630 \AA$ & $\begin{array}{l}\text { Nemec, I.; Gyepes, R.; Micka, Z.; Trojanek, F. Mat. Res. Soc. Symp. Proc. 2002, 725, } 213 . \\
\left(\mathrm{C}_{5} \mathrm{H}_{12} \mathrm{NO}_{2}\right)_{2} \mathrm{SeO}_{4} \cdot 2 \mathrm{H}_{2} \mathrm{OM} \text {.K.Marchewka, J.Janczak, S.Debrus, J.Baran, H.Ratajczak }\end{array}$ \\
\hline 60928 & $1.631 \AA$ & Takahashi, I.; Onodera, A.; Shiozaki, Y. Acta Crystallogr., Sect. C 1987, 43, 179-182. Rb $_{2} \mathrm{SeO}_{4}$ \\
\hline 73463 & $1.631 \AA$ & Fabry, J.; Breczewski, T.; Petricek, V. Acta Crystallogr., Sect. B 1993, 49, 826-832. $\mathrm{K}_{3} \mathrm{Na}\left(\mathrm{SeO}_{4}\right)_{2}$ \\
\hline 150083 & $1.631 \AA$ & $\begin{array}{l}\text { Wildner, M.; Stoilova, D.; Georgiev, M.; Karadjova, V. J. Mol. Struct. 2004, 707, 123-130. } \\
{\left[\mathrm{Be}\left(\mathrm{H}_{2} \mathrm{O}\right)_{4}\right] \mathrm{SeO}_{4}}\end{array}$ \\
\hline 710012 & $1.631 \AA$ & $\begin{array}{l}\text { Euler, H.; Barbier, B.; Meents, A.; Kirfel, A. Z. Kristallogr. - New Crystal Struct. 2009, 224, 360-364. } \\
\mathrm{Tl}_{2}\left[\mathrm{Ni}\left(\mathrm{H}_{2} \mathrm{O}\right)_{6}\right]\left(\mathrm{SeO}_{4}\right)_{2}\end{array}$ \\
\hline PRACSE10 & $1.631 \AA$ & Morosin, B.; Howatson, J. Acta Crystallogr., Sect. B 1970, 26, 2062. $\left[\mathrm{Cu}\left(\mathrm{H}_{2} \mathrm{~N}\left(\mathrm{CH}_{2}\right) \mathrm{NH}_{2}\right)_{2}\right] \mathrm{SeO}_{4} \cdot \mathrm{H}_{2} \mathrm{O}$ \\
\hline 27656 & $1.632 \AA$ & $\begin{array}{l}\text { Mehrotra, B. N.; Hahn, T.; Eysel, W.; Roepke, H.; Illguth, A. Neues Jahrbuch fuer Mineralogie. } \\
\text { Monatshefte 1978, 408-421. } \mathrm{Na}_{2} \mathrm{SeO}_{4}\end{array}$ \\
\hline
\end{tabular}




\begin{tabular}{|c|c|c|}
\hline 61183 & $1.632 \AA$ & Kruglik, A. I. Dokl. Akad. Nauk SSSR 1976, 229, 853-855. Na(NH$)\left(\mathrm{SeO}_{4}\right) \cdot 2 \mathrm{H}_{2} \mathrm{O}$ \\
\hline 158480 & $1.632 \AA$ & Krivovichev, S. V. Ukrain. Dokl. Kristallogr. 2006, 135, 80-87. $\left[\mathrm{Mg}\left(\mathrm{H}_{2} \mathrm{O}\right)_{4}\right]_{2}\left(\mathrm{SeO}_{4}\right)_{2} \cdot \mathrm{H}_{2} \mathrm{O}$ \\
\hline 200912 & $1.632 \AA$ & $\begin{array}{l}\text { Mukhtarova, N. N.; Rastsvetaeva, R. K.; Ilyukhin, V. V.; Belov, N. V. Kristallografiya 1979, } 24 N \text {, } \\
\left.\text { 1184-1192. Na[In }\left(\mathrm{H}_{2} \mathrm{O}\right)_{6}\right]\left(\mathrm{SeO}_{4}\right)_{2}\end{array}$ \\
\hline 250370 & $1.632 \AA$ & $\begin{array}{l}\text { Krivovichev, S. V. Zapiski Vserossijskogo Mineralogicheskogo Obshchestva 2006, 80-87. } \\
{\left[\mathrm{Mg}\left(\mathrm{H}_{2} \mathrm{O}\right)_{4}\right]_{2}\left(\mathrm{SeO}_{4}\right)_{2} \cdot \mathrm{H}_{2} \mathrm{O}}\end{array}$ \\
\hline 710008 & $1.632 \AA$ & $\begin{array}{l}\text { Euler, H.; Barbier, B.; Meents, A.; Kirfel, A. Z. Kristallogr. - New Crystal Struct. 2009, 224, 360-364. } \\
\mathrm{Tl}_{2}\left[\mathrm{Mg}\left(\mathrm{H}_{2} \mathrm{O}\right)_{6}\right]\left(\mathrm{SeO}_{4}\right)_{2}\end{array}$ \\
\hline RANYEK & $1.632 \AA$ & $\begin{array}{l}\text { Havlicek, D.; Plocek, J.; Nemec, I.; Gyepes, R.; Micka, Z. J. Solid State Chem. 2000, 150, } 305 . \\
\left(\mathrm{C}_{6} \mathrm{H}_{16} \mathrm{~N}_{2}\right) \mathrm{SeO}_{4} \cdot 2 \mathrm{H}_{2} \mathrm{O}\end{array}$ \\
\hline WUYXIX & $1.632 \AA$ & $\begin{array}{l}\text { Marchewka, M. K.; Janczak, J.; Debrus, S.; Baran, J.; Ratajczak, H. Solid State Sci. 2003, 5, } 643 . \\
\left(\mathrm{C}_{3} \mathrm{H}_{7} \mathrm{~N}_{6) 4}\left(\mathrm{SeO}_{4}\right)_{2} \cdot 3 \mathrm{H}_{2} \mathrm{O}\right.\end{array}$ \\
\hline 82757 & $1.633 \AA$ & $\begin{array}{l}\text { Micka, Z.; Prokopova, L.; Cisarova, I.; Havlicek, D. Coll. Czech. Chem. Commun. 1996, 61, 1295- } \\
\text { 1306. } \mathrm{Rb}_{2}\left[\mathrm{Mg}\left(\mathrm{H}_{2} \mathrm{O}\right)_{6}\right]\left(\mathrm{SeO}_{4}\right)_{2}\end{array}$ \\
\hline 174115 & $1.633 \AA$ & $\begin{array}{l}\text { Sawae, S.; Nakashima, T.; Shigematsu, H.; Kasano, H.; Mashiyama, H. J. Phys. Soc. Jpn. 2005, 74, } \\
\text { 2748-2753. }\left(\mathrm{K}_{0.52} \mathrm{Rb}_{0.48}\right)_{2} \mathrm{SeO}_{4}\end{array}$ \\
\hline 240671 & $1.633 \AA$ & Ling, J.; Albrecht-Schmitt, T. E. Inorg. Chem. 2007, 46, 346-347. $\mathrm{K}_{2} \mathrm{SeO}_{4} \cdot 2 \mathrm{HIO}_{3}$ \\
\hline 710000 & $1.633 \AA$ & $\begin{array}{l}\text { Euler, H.; Barbier, B.; Meents, A.; Kirfel, A. Z. Kristallogr. - New Crystal Struct. 2009, 224, 351-354. } \\
\mathrm{Tl}_{2}\left[\mathrm{Ni}\left(\mathrm{H}_{2} \mathrm{O}\right)_{6}\right]\left(\mathrm{SeO}_{4}\right)_{2}\end{array}$ \\
\hline 710009 & $1.633 \AA$ & $\begin{array}{l}\text { Euler, H.; Barbier, B.; Meents, A.; Kirfel, A. Z. Kristallogr. - New Crystal Struct. 2009, 224, 360-364. } \\
\mathrm{Tl}_{2}\left[\mathrm{Co}\left(\mathrm{H}_{2} \mathrm{O}\right)_{6}\right]\left(\mathrm{SeO}_{4}\right)_{2}\end{array}$ \\
\hline RANYAG & $1.633 \AA$ & $\begin{array}{l}\text { Havlicek, D.; Plocek, J.; Nemec, I.; Gyepes, R.; Micka, Z. J. Solid State Chem. 2000, 150, } 305 . \\
\left(\mathrm{C}_{4} \mathrm{H}_{12} \mathrm{~N}_{2}\right) \mathrm{SeO}_{4} \cdot \mathrm{H}_{2} \mathrm{O}\end{array}$ \\
\hline 82756 & $1.634 \AA$ & $\begin{array}{l}\text { Micka, Z.; Prokopova, L.; Cisarova, I.; Havlicek, D. Coll. Czech. Chem. Commun. 1996, 61, 1295- } \\
\text { 1306. } \mathrm{K}_{2}\left[\mathrm{Mg}\left(\mathrm{H}_{2} \mathrm{O}\right)_{6}\right]\left(\mathrm{SeO}_{4}\right)_{2}\end{array}$ \\
\hline 152720 & $1.634 \AA$ & $\begin{array}{l}\text { Litaiem, H.; Dammak, M.; Mhiri, T.; Cousson, A. J. Alloys Compd. 2005, 396, 34-39. } \\
\left(\mathrm{NH}_{4}\right)_{2} \mathrm{SeO}_{4} \cdot \mathrm{Te}(\mathrm{OH})_{6}\end{array}$ \\
\hline 158479 & $1.634 \AA$ & Krivovichev, S. V. Ukrain. Dokl. Kristallogr. 2006, 135, 96-101. $\left[\mathrm{Al}\left(\mathrm{H}_{2} \mathrm{O}\right)_{6}\right]\left(\mathrm{SeO}_{4}\right)\left(\mathrm{NO}_{3}\right) \cdot \mathrm{H}_{2} \mathrm{O}$ \\
\hline 250369 & $1.634 \AA$ & Krivovichev, S. V. Zapiski Vserossijskogo Mineralogicheskogo Obshchestva 2006, 96-101. \\
\hline
\end{tabular}


$\left[\mathrm{Al}\left(\mathrm{H}_{2} \mathrm{O}\right)_{6}\right]_{2}\left(\mathrm{SeO}_{4}\right)\left(\mathrm{NO}_{3}\right) \cdot \mathrm{H}_{2} \mathrm{O}$

\begin{tabular}{|c|c|c|}
\hline 710001 & $1.634 \AA$ & $\begin{array}{l}\text { Euler, H.; Barbier, B.; Meents, A.; Kirfel, A. Z. Kristallogr. - New Crystal Struct. 2009, 224, 351-354. } \\
\mathrm{Tl}_{2}\left[\mathrm{Zn}\left(\mathrm{H}_{2} \mathrm{O}\right)_{6}\right]\left(\mathrm{SeO}_{4}\right)_{2}\end{array}$ \\
\hline 710010 & $1.634 \AA$ & $\begin{array}{l}\text { Euler, H.; Barbier, B.; Meents, A.; Kirfel, A. Z. Kristallogr. - New Crystal Struct. 2009, 224, 360-364. } \\
\mathrm{Tl}_{2}\left[\mathrm{Cu}\left(\mathrm{H}_{2} \mathrm{O}\right)_{6}\right]\left(\mathrm{SeO}_{4}\right)_{2}\end{array}$ \\
\hline 710011 & $1.634 \AA$ & $\begin{array}{l}\text { Euler, H.; Barbier, B.; Meents, A.; Kirfel, A. Z. Kristallogr. - New Crystal Struct. 2009, 224, 360-364. } \\
\mathrm{Tl}_{2}\left[\mathrm{Mn}\left(\mathrm{H}_{2} \mathrm{O}\right)_{6}\right]\left(\mathrm{SeO}_{4}\right)_{2}\end{array}$ \\
\hline ISOMOT & $1.634 \AA$ & $\begin{array}{l}\text { Matulkova, I.; Cihelka, J.; Fejfarova, K.; Dusek, M.; Pojarova, M.; Vanek, P.; Kroupa, J.; Sala, M.; } \\
\text { Krupkova, R.; Nemec, I. CrystEngComm 2011, 13, 4131. }\end{array}$ \\
\hline 51079 & $1.635 \AA$ & $\begin{array}{l}\text { Troyanov, S. I.; Morozov, I. V.; Rybakov, V. B.; Stiewe, A.; Kemnitz, E. J. Solid State Chem. 1998, } \\
\text { 141, 317-322. } \mathrm{Cs}_{4}\left(\mathrm{SeO}_{4}\right)\left(\mathrm{HSeO}_{4}\right) 2 \cdot \mathrm{H}_{3} \mathrm{PO}_{4}\end{array}$ \\
\hline 67234 & $1.635 \AA$ & $\begin{array}{l}\text { Pietraszko, A.; Lukaszewicz, K.; Augustyniak, M. A. Acta Crystallogr., Sect. C 1992, 48, 2069-2071. } \\
\mathrm{Li}_{2} \mathrm{SeO}_{4}\end{array}$ \\
\hline 71786 & $1.635 \AA$ & $\begin{array}{l}\text { Baran, J.; Lis, T.; Marchewka, M.; Ratajczak, H. J. Mol. Struct. 1991, 250, 13-45. } \\
\mathrm{Na}_{4}\left(\mathrm{SeO}_{4}\right)\left(\mathrm{SeO}_{3}\right) \cdot \mathrm{H}_{2} \mathrm{O}\end{array}$ \\
\hline 82758 & $1.635 \AA$ & $\begin{array}{l}\text { Micka, Z.; Prokopova, L.; Cisarova, I.; Havlicek, D. Coll. Czech. Chem. Commun. 1996, 61, 1295- } \\
\text { 1306. } \mathrm{Cs}_{2}\left[\mathrm{Mg}\left(\mathrm{H}_{2} \mathrm{O}\right)_{6}\right]\left(\mathrm{SeO}_{4}\right)_{2}\end{array}$ \\
\hline 82759 & $1.635 \AA$ & $\begin{array}{l}\text { Micka, Z.; Prokopova, L.; Cisarova, I.; Havlicek, D. Coll. Czech. Chem. Commun. 1996, 61, 1295- } \\
\text { 1306. }\left(\mathrm{NH}_{4}\right)_{2}\left[\mathrm{Mg}\left(\mathrm{H}_{2} \mathrm{O}\right)_{6}\right]\left(\mathrm{SeO}_{4}\right)_{2}\end{array}$ \\
\hline 409719 & $1.635 \AA$ & $\begin{array}{l}\text { Euler, H.; Meents, A.; Barbier, B.; Kirfel, A. Z. Kristallogr. - New Cryst. Struct. 2003, 218, 265-268. } \\
\mathrm{Rb}_{2}\left[\mathrm{Mg}\left(\mathrm{H}_{2} \mathrm{O}\right)_{6}\right]\left(\mathrm{SeO}_{4}\right)_{2}\end{array}$ \\
\hline 409750 & $1.635 \AA$ & $\begin{array}{l}\text { Euler, H.; Barbier, B.; Meents, A.; Kirfel, A. Z. Kristallogr. - New Cryst. Struct. 2003, 218, 405-408. } \\
\mathrm{Rb}_{2}\left[\mathrm{Zn}\left(\mathrm{H}_{2} \mathrm{O}\right)_{6}\right]\left(\mathrm{SeO}_{4}\right)_{2}\end{array}$ \\
\hline 411002 & $1.635 \AA$ & $\begin{array}{l}\text { Troyanov, S. I.; Morozov, I. V.; Rybakov, V. B.; Kemnitz, E. Kristallografiya 2000, 45, 441-447. } \\
\mathrm{Rb}_{2} \mathrm{SeO}_{4} \cdot \mathrm{H}_{3} \mathrm{PO}_{4}\end{array}$ \\
\hline ISOMUZ & $1.635 \AA$ & $\begin{array}{l}\text { Matulkova, I.; Cihelka, J.; Fejfarova, K.; Dusek, M.; Pojarova, M.; Vanek, P.; Kroupa, J.; Sala, M.; } \\
\text { Krupkova, R.; Nemec, I. CrystEngComm 2011, 13, } 4131 .\end{array}$ \\
\hline 66526 & $1.636 \AA$ & Zuniga, F. J.; Breczewski, T.; Arnaiz, A. Acta Crystallogr., Sect. C 1991, 47, 638-640. $\mathrm{Cs}_{2} \mathrm{SeO}_{4}$ \\
\hline 409722 & $1.636 \AA$ & Euler, H.; Meents, A.; Barbier, B.; Kirfel, A. Z. Kristallogr. - New Cryst. Struct. 2003, 218, 265-268. \\
\hline
\end{tabular}




\begin{tabular}{|c|c|c|}
\hline & & $\mathrm{Rb}_{2}\left[\mathrm{Zn}\left(\mathrm{H}_{2} \mathrm{O}\right)_{6}\right]\left(\mathrm{SeO}_{4}\right)_{2}$ \\
\hline 409747 & $1.636 \AA$ & $\begin{array}{l}\text { Euler, H.; Barbier, B.; Meents, A.; Kirfel, A. Z. Kristallogr. - New Cryst. Struct. 2003, 218, 405-408. } \\
\mathrm{Rb}_{2}\left[\mathrm{Mn}\left(\mathrm{H}_{2} \mathrm{O}\right)_{6}\right]\left(\mathrm{SeO}_{4}\right)_{2}\end{array}$ \\
\hline 409748 & $1.636 \AA$ & $\begin{array}{l}\text { Euler, H.; Barbier, B.; Meents, A.; Kirfel, A. Z. Kristallogr. - New Cryst. Struct. 2003, 218, 405-408. } \\
\mathrm{Rb}_{2}\left[\mathrm{Co}\left(\mathrm{H}_{2} \mathrm{O}\right)_{6}\right]\left(\mathrm{SeO}_{4}\right)_{2}\end{array}$ \\
\hline 171281 & $1.637 \AA$ & $\begin{array}{l}\text { Simmons, C. J.; Stratemeier, H.; Hitchman, M. A.; Riley, M. J. Inorg. Chem. 2006, 45, 1021-1031. } \\
\mathrm{K}_{2}\left[\mathrm{Cu}\left(\mathrm{H}_{2} \mathrm{O}\right)_{6}\right]\left(\mathrm{SeO}_{4}\right)_{2}\end{array}$ \\
\hline 171282 & $1.637 \AA$ & $\begin{array}{l}\text { Simmons, C. J.; Stratemeier, H.; Hitchman, M. A.; Riley, M. J. Inorg. Chem. 2006, 45, 1021-1031. } \\
\mathrm{K}_{2}\left[\mathrm{Cu}\left(\mathrm{H}_{2} \mathrm{O}\right)_{6}\right]\left(\mathrm{SeO}_{4}\right)_{2}\end{array}$ \\
\hline 246302 & $1.637 \AA$ & Pertlik, F.; Fuith, A. H. Acta Crystallogr., Sect. C 1989, 45, 158-159. $\mathrm{Li}_{2} \mathrm{SeO}_{4}$ \\
\hline 409591 & $1.637 \AA$ & 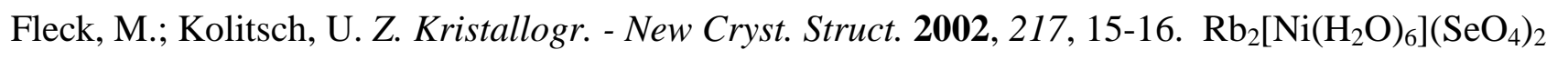 \\
\hline 409591 & $1.637 \AA$ & Fleck, M.; Kolitsch, U. Z. Kristallogr. - New Cryst. Struct. 2002, 217, 15-16. $\mathrm{Rb}_{2}\left[\mathrm{Cu}\left(\mathrm{H}_{2} \mathrm{O}\right)_{6}\right]\left(\mathrm{SeO}_{4}\right)_{2}$ \\
\hline 409669 & $1.637 \AA$ & $\begin{array}{l}\text { Euler, H.; Meents, A.; Barbier, B.; Kirfel, A. Z. Kristallogr. - New Cryst. Struct. 2003, 218, 9-10. } \\
{\left[\mathrm{Mn}\left(\mathrm{H}_{2} \mathrm{O}\right)_{4}\right] \mathrm{SeO}_{4} \cdot \mathrm{H}_{2} \mathrm{O}}\end{array}$ \\
\hline 409720 & $1.637 \AA$ & $\begin{array}{l}\text { Euler, H.; Meents, A.; Barbier, B.; Kirfel, A. Z. Kristallogr. - New Cryst. Struct. 2003, 218, 265-268. } \\
\mathrm{Rb}_{2}\left[\mathrm{Co}\left(\mathrm{H}_{2} \mathrm{O}\right)_{6}\right]\left(\mathrm{SeO}_{4}\right)_{2}\end{array}$ \\
\hline 409749 & $1.637 \AA$ & $\begin{array}{l}\text { Euler, H.; Barbier, B.; Meents, A.; Kirfel, A. Z. Kristallogr. - New Cryst. Struct. 2003, 218, 405-408. } \\
\mathrm{Rb}_{2}\left[\mathrm{Ni}\left(\mathrm{H}_{2} \mathrm{O}\right)_{6}\right]\left(\mathrm{SeO}_{4}\right)_{2}\end{array}$ \\
\hline QIXPES & $1.637 \AA$ & $\begin{array}{l}\text { Maubert, B. M.; Nelson, J.; McKee, V.; Town, R. M.; Pal, I. J.Chem.Soc., Dalton Trans. 2001, } 1395 . \\
\left(\mathrm{C}_{36} \mathrm{H}_{60} \mathrm{~N}_{8}\right) \mathrm{SeO}_{4}\left(\mathrm{ClO}_{4}\right)_{4} \cdot \mathrm{H}_{2} \mathrm{O}\end{array}$ \\
\hline FAKVEU & $1.637 \AA$ & Kammoun, O.; Loulou, N.; Rekik, W.; Naili, H.; Mhiri, T.; Bataille, T. J. Chem. Cryst. 2012, 42, 103. \\
\hline 89440 & $1.638 \AA$ & Pietraszko, A.; Bronowska, W. Solid State Commun. 1999, 111, 205-209. $\mathrm{Rb}_{2} \mathrm{Li}_{4}\left(\mathrm{SeO}_{4}\right)_{3} \cdot 2 \mathrm{H}_{2} \mathrm{O}$ \\
\hline 150084 & $1.638 \AA$ & $\begin{array}{l}\text { Wildner, M.; Stoilova, D.; Georgiev, M.; Karadjova, V. J. Mol. Struct. 2004, 707, 123-130. } \\
{\left[\mathrm{Be}\left(\mathrm{H}_{2} \mathrm{O}\right)_{4}\right] \mathrm{SeO}_{4}}\end{array}$ \\
\hline 150706 & $1.638 \AA$ & Fukami, T.; Chen Rueyhong J. Phys. Soc. Jpn. 2003, 72, 3299-3300. $\mathrm{Na}_{2} \mathrm{SeO}_{4}$ \\
\hline 171280 & $1.638 \AA$ & $\begin{array}{l}\text { Simmons, C. J.; Stratemeier, H.; Hitchman, M. A.; Riley, M. J. Inorg. Chem. 2006, 45, 1021-1031. } \\
\mathrm{K}_{2}\left[\mathrm{Cu}\left(\mathrm{H}_{2} \mathrm{O}\right)_{6}\right]\left(\mathrm{SeO}_{4}\right)_{2}\end{array}$ \\
\hline 409648 & $1.638 \AA$ & Fleck, M.; Kolitsch, U. Z. Kristallogr. - New Cryst. Struct. 2002, 217, 471-473. \\
\hline
\end{tabular}


$\left(\mathrm{NH}_{4}\right)_{2}\left[\mathrm{Co}\left(\mathrm{H}_{2} \mathrm{O}\right)_{6}\right]\left(\mathrm{SeO}_{4}\right)_{2}$

\begin{tabular}{|c|c|c|}
\hline 409721 & $1.638 \AA$ & $\begin{array}{l}\text { Euler, H.; Meents, A.; Barbier, B.; Kirfel, A. Z. Kristallogr. - New Cryst. Struct. 2003, 218, 265-268. } \\
\mathrm{Rb}_{2}\left[\mathrm{Mn}\left(\mathrm{H}_{2} \mathrm{O}\right)_{6}\right]\left(\mathrm{SeO}_{4}\right)_{2}\end{array}$ \\
\hline 409746 & $1.638 \AA$ & $\begin{array}{l}\text { Euler, H.; Barbier, B.; Meents, A.; Kirfel, A. Z. Kristallogr. - New Cryst. Struct. 2003, 218, 405-408. } \\
\mathrm{Rb}_{2}\left[\mathrm{Mg}\left(\mathrm{H}_{2} \mathrm{O}\right)_{6}\right]\left(\mathrm{SeO}_{4}\right)_{2}\end{array}$ \\
\hline 419776 & $1.638 \AA$ & Grzechnik, A.; Breczewski, T.; Friese, K. J. Solid State Chem. 2008, 181, 2914-2917. $\mathrm{Tl}_{2} \mathrm{SeO}_{4}$ \\
\hline 154512 & $1.639 \AA$ & Dammak, M.; Mhiri, T.; Cousson, A. J. Alloys Compd. 2006, 407, 176-181. $\mathrm{K}_{2} \mathrm{SeO}_{4} \cdot \mathrm{Te}(\mathrm{OH})_{6}$ \\
\hline 200156 & $1.639 \AA$ & $\begin{array}{l}\text { Mukhtarova, N. N.; Rastsvetaeva, R. K.; Ilyukhin, V. V.; Belov, N. V. Dokl. Akad. Nauk SSSR 1977, } \\
\text { 235, 575-577. } \mathrm{Na}\left[\operatorname{In}\left(\mathrm{H}_{2} \mathrm{O}\right)_{6}\right]\left(\mathrm{SeO}_{4}\right)_{2}\end{array}$ \\
\hline 201893 & $1.639 \AA$ & Yamada, N.; Ono, Y.; Ikeda, T. J. Phys. Soc. Jpn. 1984, 53, 2565-2574. $\mathrm{K}_{2} \mathrm{SeO}_{4}$ \\
\hline 280788 & $1.639 \AA$ & Kolitsch, U. Acta Crystallogr., Sect. E 2002, 58, 3-5. [ $\left[\mathrm{Mg}\left(\mathrm{H}_{2} \mathrm{O}\right)_{6}\right] \mathrm{SeO}_{4}$ \\
\hline 409649 & $1.639 \AA$ & $\begin{array}{l}\text { Fleck, M.; Kolitsch, U. Z. Kristallogr. - New Cryst. Struct. 2002, 217, 471-473. } \\
\left(\mathrm{NH}_{4}\right)_{2}\left[\mathrm{Zn}\left(\mathrm{H}_{2} \mathrm{O}\right)_{6}\right]\left(\mathrm{SeO}_{4}\right)_{2}\end{array}$ \\
\hline KARFIU & $1.639 \AA$ & Daszkiewicz, M.; Marchewka, M. M. Vibr. Spectr. 2011, 57, 326. \\
\hline 201740 & $1.640 \AA$ & $\begin{array}{l}\text { Mascherpa-Corral, D.; Ducourant, M. B.; Fourcade, R.; Mascherpa, G.; Alberola, S. J. Solid State } \\
\text { Chem. 1986, 63, 52-61. } \mathrm{K}_{2} \mathrm{SeO}_{4} \cdot 2 \mathrm{SbF}_{3} \cdot \mathrm{H}_{2} \mathrm{O}\end{array}$ \\
\hline 60929 & $1.641 \AA$ & Takahashi, I.; Onodera, A.; Shiozaki, Y. Acta Crystallogr., Sect. C 1987, 43, 179-182. $\mathrm{Rb}_{2} \mathrm{SeO}_{4}$ \\
\hline 171279 & $1.641 \AA$ & $\begin{array}{l}\text { Simmons, C. J.; Stratemeier, H.; Hitchman, M. A.; Riley, M. J. Inorg. Chem. 2006, 45, 1021-1031. } \\
\mathrm{K}_{2}\left[\mathrm{Cu}\left(\mathrm{H}_{2} \mathrm{O}\right)_{6}\right]\left(\mathrm{SeO}_{4}\right)_{2}\end{array}$ \\
\hline 280783 & $1.641 \AA$ & Kolitsch, U. Acta Crystallogr., Sect. E 2001, 57, 104-105. $\left[\mathrm{Cu}\left(\mathrm{H}_{2} \mathrm{O}\right)_{4}\right] \mathrm{SeO}_{4} \cdot \mathrm{H}_{2} \mathrm{O}$ \\
\hline 163455 & $1.642 \AA$ & $\begin{array}{l}\text { Amri, M.; Zouari, N.; Mhiri, T.; Gravereau, P. J. Alloys Compd. 2009, 477, 68-75. } \\
\left.\mathrm{Cs}_{4}\left(\mathrm{SeO}_{4}\right)\left(\mathrm{HSeO}_{4}\right)_{2}\right) \cdot \mathrm{H}_{3} \mathrm{AsO}_{4}\end{array}$ \\
\hline 201882 & $1.642 \AA$ & Yamada, N.; Ikeda, T. J. Phys. Soc. Jpn. 1984, 53, 2555-2564. $\mathrm{K}_{2} \mathrm{SeO}_{4}$ \\
\hline DEHQIR & $1.642 \AA$ & Jun-Jieh Wang; Tessier, C.; Holm, R. H. Inorg. Chem. 2006, 45, 2979. $\left(\mathrm{C}_{8} \mathrm{H}_{20} \mathrm{~N}\right)_{2} \mathrm{SeO}_{4} \cdot \mathrm{CH}_{3} \mathrm{CN}$ \\
\hline 838 & $1.644 \AA$ & Carter, R.; Koerntgen, C.; Margulis, T. N. Acta Crystallogr., Sect. B 1977, 33, 592-593. $\left(\mathrm{NH}_{4}\right)_{2} \mathrm{SeO}_{4}$ \\
\hline 154671 & $1.644 \AA$ & $\begin{array}{l}\text { Dammak, M.; Litaiem, H.; Mhiri, T. J. Alloys Compd. 2006, 416, 228-235. } \\
\mathrm{Na}_{2} \mathrm{SeO}_{4} \cdot \mathrm{Te}(\mathrm{OH})_{6} \cdot 0.5 \mathrm{H}_{2} \mathrm{O}\end{array}$ \\
\hline 171283 & $1.644 \AA$ & Simmons, C. J.; Stratemeier, H.; Hitchman, M. A.; Riley, M. J. Inorg. Chem. 2006, 45, 1021-1031. \\
\hline
\end{tabular}




\begin{tabular}{|c|c|c|}
\hline & & $\mathrm{K}_{2}\left[\mathrm{Cu}\left(\mathrm{H}_{2} \mathrm{O}\right)_{6}\right]\left(\mathrm{SeO}_{4}\right)_{2}$ \\
\hline WULSAY & $1.644 \AA$ & $\begin{array}{l}\text { Wen Zhang; Li-Zhuang Chen; Ren-Gen Xiong; Nakamura; T.; Huang, S. D. J. Am. Chem. Soc. 2009, } \\
\text { 131, } 12544 .\end{array}$ \\
\hline WULSAY02 & $1.644 \AA$ & $\begin{array}{l}\text { Wen Zhang; Li-Zhuang Chen; Ren-Gen Xiong; Nakamura; T.; Huang, S. D. J. Am. Chem. Soc. 2009, } \\
\text { 131, 12544. }\end{array}$ \\
\hline DGLYSE & $1.645 \AA$ & Olejnik, S.; Lukaszewicz, K.; Lis, T. Acta Crystallogr., Sect. B 1975, 31, 1785. $\left(\mathrm{C}_{2} \mathrm{H}_{6} \mathrm{NO}_{2}\right)_{2} \mathrm{SeO}_{4}$ \\
\hline OKOKOP & $1.645 \AA$ & Custelcean, R.; Bock, A.; Moyer, B. A. J. Am. Chem. Soc. 2010, 132, 7177. \\
\hline 202659 & $1.646 \AA$ & $\begin{array}{l}\text { Mascherpa-Corral, D.; Ducourant, M. B.; Alberola, S. J. Solid State Chem. 1988, 76, 276-283. } \\
\mathrm{K}_{2} \mathrm{SeO}_{4} \cdot 2 \mathrm{SbF}_{3} \cdot 0.5 \mathrm{H}_{2} \mathrm{O}\end{array}$ \\
\hline LATUMS & $1.648 \AA$ & $\begin{array}{l}\text { Kono, Y.; Takeuchi, S.; Yonehara, H.; Marumo, F.; Saito, Y. Acta Crystallogr., Sect. B 1971, } 27 \text {, } \\
\text { 2341. }\left(\mathrm{C}_{10} \mathrm{H}_{12} \mathrm{NO}\right) \mathrm{SeO}_{4}\end{array}$ \\
\hline 15816 & $1.649 \AA$ & Naray-Szabo, I.; Argay, G. Acta Chim. Acad. Sci. Hung. 1963, 39, 85-92. $\mathrm{Na}_{2} \mathrm{SeO}_{4}$ \\
\hline 99384 & $1.653 \AA$ & $\begin{array}{l}\text { Friese, K.; Goeta, A. E.; Leech, M. A.; Howard, J. A. K.; Madariaga, G.; Perez-Mato, J. M.; } \\
\text { Breczewski, T. J. Solid State Chem. 2004, 177, 1127-1136. } \mathrm{Tl}_{2} \mathrm{SeO}_{4}\end{array}$ \\
\hline 16042 & $1.654 \AA$ & Kalman, A.; Cruickshank, D. W. J. Acta Crystallogr., Sect. B 1970, 26, 436-436. $\mathrm{Na}_{2} \mathrm{SeO}_{4}$ \\
\hline 160682 & $1.671 \AA$ & $\begin{array}{l}\text { Smirnov, L. S.; Melnyk, G.; Zink, N.; Wozniak, K.; Dominiak, P.; Pawlukojc, A.; Loose, A.; } \\
\text { Shuvalov, L. A. Poverkhnostnye Fizika, Khimiya, Mekhanika 2007, 73-79. }\left(\mathrm{NH}_{4}\right)_{2}\left(\mathrm{SeO}_{4}\right)_{2}\end{array}$ \\
\hline \multicolumn{3}{|c|}{ Mean $1.634 \AA ̊ ̊ 1 / 108$} \\
\hline \multicolumn{3}{|c|}{ Hydrogenselenate ion, $\mathrm{HSeO}_{4}^{-}$} \\
\hline SAQHOH & $1.587+1.695 \AA$ & $\begin{array}{l}\text { Baran, J.; Barnes, A. J.; Marchewka, M. K.; Pietraszko, A. J.; Ratajczak, H. J. Mol. Struct. 1997, 416, } \\
\text { 33. }\left(\mathrm{C}_{5} \mathrm{H}_{12} \mathrm{NO}_{2}\right)\left(\mathrm{HSeO}_{4}\right)_{2}\left(\mathrm{C}_{5} \mathrm{H}_{11} \mathrm{NO}_{2}\right) \cdot \mathrm{H}_{2} \mathrm{O}\end{array}$ \\
\hline 163455 & $1.596+1.730 \AA$ & $\begin{array}{l}\text { Amri, M.; Zouari, N.; Mhiri, T.; Gravereau, P. J. Alloys Compd. 2009, 477, 68-75. } \\
\left.\mathrm{Cs}_{4}\left(\mathrm{SeO}_{4}\right)\left(\mathrm{HSeO}_{4}\right)_{2}\right) \cdot \mathrm{H}_{3} \mathrm{AsO}_{4}\end{array}$ \\
\hline SUVQAB & $1.597+1.685 \AA$ & Slouf, M.; Cisarova, I. Acta Crystallogr., Sect. C 1999, 55, 9900003. $\left(\mathrm{C}_{13} \mathrm{H}_{10} \mathrm{~N}\right)\left(\mathrm{HSeO}_{4}\right)_{3} \cdot \mathrm{H}_{2} \mathrm{O}$ \\
\hline 31997 & $1.603+1.714 \AA$ & Waskowska, A.; Czapla, Z. Acta Crystallogr., Sect. B 1982, 38, 2017-2020. RbDSeO $_{4}$ \\
\hline AJEROX & $1.605+1.693 \AA$ & Akriche, S.; Rzaigui, M. Acta Crystallogr., Sect. E 2009, 65, o3009. \\
\hline
\end{tabular}


LEJCIN $\quad 1.607+1.696 \AA$ Hamilton, E. E.; Fanwick, P. E.; Wilker, J. J. J. Am. Chem. Soc. 2006, 128, 3388. $\left(\mathrm{C}_{24} \mathrm{H}_{20} \mathrm{P}\right)_{3}\left(\mathrm{CH}_{2} \mathrm{O}_{8} \mathrm{Se}_{2}\right)\left(\mathrm{HSeO}_{4}\right)$

NASQIH $\quad$ 1.608+1.688 ̊̊ Baran, J.; Drozd, M.; Lis, T.; Sledz, M.; Barnes, A. J.; Ratajczak, H. J. Mol. Struct. $1995,372,29$. $\left.\left(\mathrm{C}_{5} \mathrm{H}_{12} \mathrm{NO}_{2}\right)\left(\mathrm{HSeO}_{4}\right)_{2}\right) \cdot \mathrm{H}_{2} \mathrm{O}$

$51079 \quad 1.609+1.735$ A Troyanov, S. I.; Morozov, I. V.; Rybakov, V. B.; Stiewe, A.; Kemnitz, E. J. Solid State Chem. 1998, 141, 317-322. $\mathrm{Cs}_{4}\left(\mathrm{SeO}_{4}\right)\left(\mathrm{HSeO}_{4}\right)_{2} \cdot \mathrm{H}_{3} \mathrm{PO}_{4}$

HESNAV $\quad 1.609+1.716 \AA \quad$ Fleck, M. Acta Crystallogr., Sect. E 2006, 62, o4939. $\mathrm{CH}_{6} \mathrm{~N}_{3}\left(\mathrm{HSeO}_{4}\right)$

$51080 \quad 1.610+1.670 \AA$ Troyanov, S. I.; Morozov, I. V.; Rybakov, V. B.; Stiewe, A.; Kemnitz, E. J. Solid State Chem. 1998, 59150141, 317-322. $\mathrm{Cs}_{3}\left(\mathrm{HSeO}_{4}\right)_{2}\left(\mathrm{H}_{2} \mathrm{PO}_{4}\right)$

XINBEB $\quad 1.610+1.725 \AA \quad$ Zakharov, M. A.; Troyanov, S. I.; Rybakov, V. B.; Aslanov, L. A.; Kemnitz, E. Kristallografiya 2001, 46, 1057. $\left(\mathrm{C}_{4} \mathrm{H}_{12} \mathrm{~N}\right)\left(\mathrm{HSeO}_{4}\right)$

XINBEB01 1.610+1.725 ̊ Zakharov, M. A.; Troyanov, S. I.; Rybakov, V. B.; Aslanov, L. A.; Kemnitz, E. Kristallografiya 2001, 46, 1057. $\left(\mathrm{C}_{4} \mathrm{H}_{12} \mathrm{~N}\right)\left(\mathrm{HSeO}_{4}\right)$

$35456 \quad 1.611+1.692 \AA \quad$ Brach, I.; Jones, D. J.; Roziere, J. J. Solid State Chem. 1983, 48, 401-406. RbHSeO 4

YOVPIJ $\quad 1.611+1.701 \AA \quad$ Akriche, S.; Rzaigui, M. Acta Crystallogr., Sect. E 2009, 65, o1648.

HESNAV01 1.611+1.712 ̊ Drozd, M.; Baran, J.; Pietraszko, A. Spectrochim. Acta, Part A 2005, 61, 2775. $\mathrm{CH}_{6} \mathrm{~N}_{3}\left(\mathrm{HSeO}_{4}\right)$

$85082 \quad 1.615+1.718 \AA \quad$ Hanashiro, K.; Koyano, N.; Machida, M. Kyoto Daigaku Genshiro Jikkensko Gakujutsu Koenkai Hobunshu 1997, 31, 189-192. $\mathrm{KHSeO}_{4}$

$888831.615+1.700$ Å Troyanov, S. I.; Morozov, I. V.; Zakharov, M. A.; Kemnitz, E. Kristallografiya 1999, 44, 607-611. $\mathrm{Cs}\left(\mathrm{HSeO}_{4}\right) \cdot \mathrm{H}_{2} \mathrm{SeO}_{4}$

TIPNAI $\quad 1.616+1.704 \AA \quad$ Krivovichev, S. V.; Tananaev, I. G.; Myasoedov, B. F. Compt. Rend. Chim. $2007,10,897$.

$88882 \quad 1.616+1.719 \AA \quad$ Troyanov, S. I.; Morozov, I. V.; Zakharov, M. A.; Kemnitz, E. Kristallografiya 1999, 44, 607-611. $\mathrm{K}\left(\mathrm{HSeO}_{4}\right) \cdot \mathrm{H}_{2} \mathrm{SeO}_{4}$

$88893 \quad$ 1.617+1.727 ̊ Zakharov, M. A.; Troyanov, S. I.; Rybakov, V. B.; Aslanov, L. A.; Kemnitz, E. Kristallografiya 1999, 44, 448-453. $\mathrm{NaHSeO}_{4}$

$51081 \quad 1.617+1.635 \AA \quad$ Troyanov, S. I.; Morozov, I. V.; Rybakov, V. B.; Stiewe, A.; Kemnitz, E. J. Solid State Chem. 1998, 141, 317-322. $\mathrm{Cs}_{5}\left(\mathrm{HSeO}_{4}\right)_{3}\left(\mathrm{H}_{2} \mathrm{PO}_{4}\right)_{2}$

$65810 \quad 1.618+1.715 \AA \quad$ Makarova, I. P.; Rider, E. E.; Sarin, V. A.; Aleksandrova, I. P.; Simonov, V. I. Kristallografiya 1989, 34, 853-861. $\mathrm{RbHSeO}_{4}$ 
IGABIC

72535

168568

300018

31998

65809

71198

72533

411282

72536

20794

20829

94517
XOMVAX 1.626+1.724 Å Lorenc, J.; Bryndal, I.; Marchewka, M.; Kucharska, E.; Lis, T.; Hanuza, J. J. Raman Spectrosc. 2008,

$1.618+1.715 \AA \quad$ Makarova, I. P. Acta Crystallogr., Sect. B 1993, 49, 11-18. $\mathrm{RbHSeO}_{4}$

1.618+1.701 А̊ Fukami, T.; Miyazaki, J.; Tomimura, T.; Chen R.-H. Cryst. Res. Technol. 2010, 45, 856-862. $\mathrm{Na}_{5} \mathrm{D}_{3}\left(\mathrm{SeO}_{4}\right)_{4} \cdot 2 \mathrm{H}_{2} \mathrm{O}_{2}$

1.618+1.705 ^ Maalej, W.; Elaoud, Z.; Mhiri, T.; Daoud, A.; Driss, A. Acta Crystallogr., Sect. E 2008, 64, o2172.

1.619+1.693 А Makarova, I. P. Acta Crystallogr., Sect. B 1993, 49, 11-18. $\mathrm{NH}_{4} \mathrm{HSeO}_{4}$

1.619+1.700 ̊ Fukami, T.; Miyazaki, J.; Tomimura, T.; Chen R.-H. Cryst. Res. Technol. 2010, 45, 856-862. $\mathrm{Na}_{5} \mathrm{H}_{3}\left(\mathrm{SeO}_{4}\right)_{4} \cdot 2 \mathrm{H}_{2} \mathrm{O}_{2}$

1.620+1.707 ^ Waskowska, A.; Olejnik, S.; Lukaszewicz, K.; Czapla, Z. Cryst. Struct. Commun. 1980, 9, $663-669$. $\mathrm{Rb}\left(\mathrm{HSeO}_{4}\right)$

1.621+1.715 ̊ Waskowska, A.; Czapla, Z. Acta Crystallogr., Sect. B 1982, 38, 2017-2020. ( $\left.\mathrm{ND}_{4}\right) \mathrm{DSeO}_{4}$

1.622+1.694 A Makarova, I. P.; Rider, E. E.; Sarin, V. A.; Aleksandrova, I. P.; Simonov, V. I. Kristallografiya 1989, 34, 853-861. $\mathrm{RbHSeO}_{4}$

1.622+1.694 ^ Makarova, I. P.; Muradyan, L. A.; Rider, E. E.; Sarin, V. A.; Alexandrova, I. P.; Simonov, V. I. Ferroelectrics 1990, 107, 281-286. $\mathrm{RbHSeO}_{4}$

$1.622+1.694 \AA \quad$ Makarova, I. P. Acta Crystallogr., Sect. B 1993, 49, 11-18. $\mathrm{RbHSeO}_{4}$

1.622+1.723 ̊ Zakharov, M. A.; Troyanov, S. I.; Kemnitz, E. Z. Kristallogr. 2001, 216, 172-175. Cs(HSeO $\left.\mathrm{H}_{4}\right)$

1.624+1.690 А Makarova, I. P. Acta Crystallogr., Sect. B 1993, 49, 11-18. $\mathrm{NH}_{4} \mathrm{HSeO}_{4}$

1.626+1.694 Å Kruglik, A. I.; Misyul', S. V.; Aleksandrov, K. S. Dokl. Akad. Nauk SSSR 1980, 255, 344-348. $\left(\mathrm{NH}_{4}\right) \mathrm{HSeO}_{4}$

1.626+1.686 A $\quad$ Aleksandrov, K. S.; Kruglik, A. I.; Misyul', S. V.; Simonov, M. A. Kristallografiya 1980, 25N, 11421147. $\left(\mathrm{NH}_{4}\right) \mathrm{HSeO}_{4}$

1.626+1.715 ̊ Troyanov, S. I.; Kosterina, E. V.; Kemnitz, E. Zh. Neorg. Khim. 2001, 46, 1496-1502. $\mathrm{Cs}_{4}\left(\mathrm{SeO}_{4}\right)\left(\mathrm{HSeO}_{4}\right)_{2} \cdot \mathrm{HF}$ 39, 863.

1.631+1.712 ^ Waskowska, A.; Olejnik, S.; Lukaszewicz, K.; Glovyak, T. Acta Crystallogr., Sect. B 1978, 34, 33443346. $\mathrm{RbHSeO}_{4}$

1.631+1.735 ̊ Baran, J.; Lis, T. Acta Crystallogr., Sect. C 1986, 42, 270-272. $\mathrm{KHSeO}_{4}$ 
Selenic acid, $\mathrm{H}_{2} \mathrm{SeO}_{4}$

$888831.590+1.687 \AA$

Troyanov, S. I.; Morozov, I. V.; Zakharov, M. A.; Kemnitz, E. Kristallografiya 1999, 44, 607-611. $\mathrm{Cs}\left(\mathrm{HSeO}_{4}\right) \cdot \mathrm{H}_{2} \mathrm{SeO}_{4}$

$888821.603+1.685 \AA$ A $\quad$ Troyanov, S. I.; Morozov, I. V.; Zakharov, M. A.; Kemnitz, E. Kristallografiya 1999, 44, 607-611. $\mathrm{K}\left(\mathrm{HSeO}_{4}\right) \cdot \mathrm{H}_{2} \mathrm{SeO}_{4}$

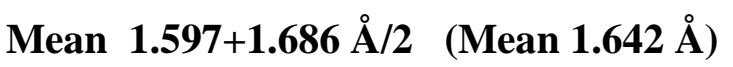

